\title{
Natural and genetically engineered proteins for tissue engineering
}

\author{
Sílvia Gomes ${ }^{a, b, c, 1}$, Isabel B. Leonor ${ }^{a, b, 1}$, João F. Mano ${ }^{a, b, 1}$, Rui L. Reis ${ }^{a, b, 1}$, \\ David L. Kaplan ${ }^{\mathrm{c}, *}$ \\ a 3B's Research Group - Biomaterials, Biodegradables and Biomimetics, Department of Polymer Engineering, University of Minho, Headquarters of the \\ European Institute of Excellence on Tissue Engineering and Regenerative Medicine, AvePark, Zona Industrial da Gandra, S. Claudio do Barco, $4806-909$ Caldas \\ das Taipas, Guimarães, Portugal \\ b IBB - Institute for Biotechnology and Bioengineering, PT Government Associated Laboratory, Braga, Portugal \\ c Departments of Biomedical Engineering, Chemistry and Physics, Tufts University, Medford, MA 02155, USA
}

\section{A R T I C L E I N F O}

\section{Article history:}

Received 1 February 2011

Received in revised form 6 July 2011

Accepted 6 July 2011

Available online 18 July 2011

\section{Keywords:}

Biomaterials

Tissue engineering

Natural polymers

Recombinant technology

Chimeric proteins

\begin{abstract}
A B S T R A C T
To overcome the limitations of traditionally used autografts, allografts and, to a lesser extent, synthetic materials, there is the need to develop a new generation of scaffolds with adequate mechanical and structural support, control of cell attachment, migration, proliferation and differentiation and with bio-resorbable features. This suite of properties would allow the body to heal itself at the same rate as implant degradation. Genetic engineering offers a route to this level of control of biomaterial systems. The possibility of expressing biological components in nature and to modify or bioengineer them further, offers a path towards multifunctional biomaterial systems. This includes opportunities to generate new protein sequences, new self-assembling peptides or fusions of different bioactive domains or protein motifs. New protein sequences with tunable properties can be generated that can be used as new biomaterials.

In this review we address some of the most frequently used proteins for tissue engineering and biomedical applications and describe the techniques most commonly used to functionalize protein-based biomaterials by combining them with bioactive molecules to enhance biological performance. We also highlight the use of genetic engineering, for protein heterologous expression and the synthesis of new protein-based biopolymers, focusing the advantages of these functionalized biopolymers when compared with their counterparts extracted directly from nature and modified by techniques such as physical adsorption or chemical modification.
\end{abstract}

(c) 2011 Elsevier Ltd. All rights reserved.

\section{Contents}

1. Introduction

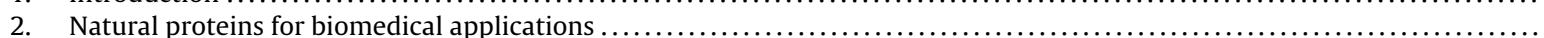

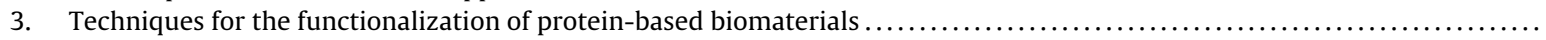

4. Recombinant proteins for tissue engineering.

\footnotetext{
* Corresponding author at: Departments of Biomedical Engineering, Chemistry and Physics, 4 Colby, Street, Rm. 251, Tufts University, Medford, MA 02155, USA. Tel.: +1 617627 3251; fax: +16176273231.

E-mail addresses: silvia.gomes@dep.uminho.pt (S. Gomes), belinha@dep.uminho.pt (I.B. Leonor),jmano@dep.uminho.pt (J.F. Mano), rgreis@dep.uminho.pt (R.L. Reis), David.Kaplan@tufts.edu (D.L. Kaplan).

1 Tel.: +351253510 900; fax: +351253510909.
} 


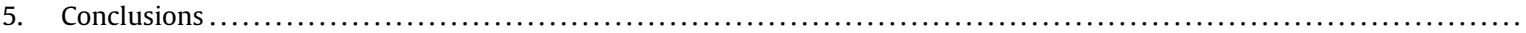

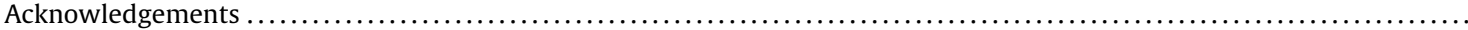

\section{Introduction}

Treatment of injured tissues or organs focuses on the use of autologous and allogenic grafts [1]. However, this practice has significant limitations for the patient and health systems worldwide. Autologous grafts cause donor site morbidity and consequent loss of organ functionality. Allografts are associated with risk of disease transmission and require the use of immunosuppressants with associated side effects [2-4]. In the field of orthopaedic implants, autologous and allogenic grafts account for $90 \%$ of the grafts currently used, with synthetic materials (metals, polymers, ceramics and composite systems) used in $10 \%$ of surgery cases $[3,5,6]$. In the three types of grafts there are numerous cases of implant failure as a consequence of undesirable local tissue responses resulting in implant loosening, insufficient osseointegration, osteolysis, inflammation and infection [2-4]. These complications account for a failure rate of $13-30 \%$ in the case of autografts and $20-40 \%$ for allografts [2]. Besides autologous and allogenic grafts, synthetic materials have also been used for controlled drug delivery systems, scaffolds design and orthopaedic fixation as screws, pins or rods $[7,8]$. Nevertheless, most synthetic polymers are too hydrophobic and need additional bulk or surface modifications to render the material more biocompatible and suitable for implantation [9]. Therefore, there is a need for alternatives to these practices. Tissue engineering and regenerative medicine offer an approach to circumvent the present therapies with new methods of health care treatment with the purpose of improving the quality of life $[2,10]$. This improvement can come in the form of new cytocompatible and non-toxic biomaterials for the manufacture of a new generation of scaffolds comprising adequate mechanical and structural support and able to control cell attachment, migration, proliferation and differentiation $[11,12]$. Furthermore, this future generation of scaffolds should not behave as a permanent prosthesis but instead should perform as bio-resorbable temporary implants, allowing for the body to heal itself at the same rate as the implant degradation $[11,13]$.

In recent years a small number of synthetic biodegradable polymers, mainly polyesters containing glycolic (PLG) or lactic (PLL) acids and caprolactone (PCL) were approved by the Food and Drug Administration (FDA) for use in sutures [13]. Epicel ${ }^{\mathrm{TM}}$ (autologous keratinocyte skin graft to treat severe burn victims from Genzyme Biosurgery, Cambridge, MA), Carticel ${ }^{\circledR}$ (autologous chondrocyte transplantation to treat cartilage injury from Genzyme Biosurgery, Cambridge, MA) [14], MACI ${ }^{\mathrm{TM}}$ for matrix-induced autologous chondrocyte implantation (Genzyme Biosurgery, Cambridge, MA) where chondrocytes are supplied seeded onto a type I/III collagen scaffold secured to the skin injury with fibrin glue [15], and Apligraf (bovine collagen I matrix seeded with keratinocytes for wound care from Organogenesis, Canton, MA) [16], are products for cell therapy also available in the market. Other examples of products already commercially available are Atrigel ${ }^{\circledR}$ (Atrix Laboratories, Fort Collins, CO, USA) a system of biodegradable polymers for drug delivery [17] and the calcium phosphate based products Collagraft (Zimmer, Warsaw, IN; and Collagen Corporation, Palo Alto, CA) and ProOsteon (Interpore international, Irvine, CA) for bone applications [2]. However, since giving a detailed description of these and other products available in the market is not the purpose of this review we advise the reader to address other reports for more information [2,13-17].

Despite the enormous research effort during the last few decades materials scientist have not fully developed a new generation of biocompatible biomaterials [13]. This limitation of tissue engineering to move forward from the laboratory into the clinic is the result of many issues, including legal, the need to develop functional blood vessel networks to nourish the new tissues mainly inside scaffolds, inability of the biomaterials to promote the formation of functional tissues, and many related issues [13]. For these reasons it is critical to develop the next generation of biomaterials that will address the limitations above. New approaches in the fields of bionanotechnology, protein engineering and bionano-fabrication will play a role in the development of these next generation biomaterials [18-20].

In this review we address some biopolymers already being used or with potential applications in regenerative medicine and tissue engineering, giving special focus to proteins and protein-based biomaterials. Additionally, we will also focus on the different approaches used for functionalization of these biomaterials in order to improve performance, mechanical efficiency, biocompatibility and degradability, usually with a goal towards control of these processes. This overview will be followed by a description of the novel design approaches, namely genetic engineering, enabling the synthesis of new protein-based biopolymers inspired in nature but without many of the drawbacks of their native counterparts when extracted directly from natural sources. Additional information can be found in recent reviews addressing the use of biomimetic materials in tissue engineering [21], the application of protein templates for tissue engineering [12], the synthetic modification of proteins and peptides [22] and the use of bioengineering for biomaterials design $[19,20]$.

\section{Natural proteins for biomedical applications}

The similarity between natural polymers and the macromolecules forming extracellular matrices suggests an innate ability for some of these polymers to interact with the cells and the biomolecules present in host tissues, inducing mild immunological reactions when compared with synthetic materials [11,23,24]. Natural polymers such as fibrin, fibronectin, collagen, elastin, silk, keratin, chitosan, alginate, amylose/amylopectin and hyaluronic acid are widely used in tissue engineering $[23,25]$. Within the 
Table 1

Basic features of some proteins with potential applications in the biomedical field.

\begin{tabular}{|c|c|c|c|}
\hline Protein & Main functions & Basic structure & Relevant properties \\
\hline Collagen $[31,34]$ & $\begin{array}{l}\text { Structural protein in tissues such } \\
\text { as connective tissue, tendon, skin, } \\
\text { bone and cartilage }\end{array}$ & $\begin{array}{l}\text { Three parallel polypeptide chains } \\
\text { formed by GXY (G - glycine, X - } \\
\text { usually proline, Y - usually } \\
\text { 4-hydroxyproline) repeats and } \\
\text { arranged in triple helix }\end{array}$ & $\begin{array}{l}\text { Biodegradability, low antigenecity } \\
\text { and biocompatibility }\end{array}$ \\
\hline Fibronectin $[47,49]$ & $\begin{array}{l}\text { Structural support and cell } \\
\text { signalling }\end{array}$ & $\begin{array}{l}\text { Dimer of two non-identical } \\
\text { polypetide chains bonded at the } \\
\text { carboxyl end by disulfide bonds }\end{array}$ & $\begin{array}{l}\text { Multi-domain protein with cell (RGD } \\
\text { motif), collagen and fibrin binding } \\
\text { motifs }\end{array}$ \\
\hline Elastin $[56,182,183]$ & $\begin{array}{l}\text { Structural protein found } \\
\text { predominantly in connective } \\
\text { tissue of arteries, ligaments, skin } \\
\text { and lung }\end{array}$ & $\begin{array}{l}\text { Cross-linked units of tropoelastin } \\
\text { formed by hydrophobic (often 3-6 } \\
\text { repeats of GVGVP, GGVP and } \\
\text { GVGVAP) and hydrophilic lysine } \\
\text { domains }\end{array}$ & $\begin{array}{l}\text { Temperature dependent } \\
\text { self-assembly and phase separation } \\
\text { behaviour }\end{array}$ \\
\hline Fibrin $[72,184]$ & $\begin{array}{l}\text { Blood clotting, fibrinolysis, } \\
\text { cellular and matrix interactions, } \\
\text { inflammation and wound healing }\end{array}$ & $\begin{array}{l}\text { Resultant from the polymerization } \\
\text { and crosslinking of fibrinogen units } \\
\text { after thrombin cleavage }\end{array}$ & $\begin{array}{l}\text { Growth factor binding and } \\
\text { interaction with cells such as } \\
\text { platelets, leucocytes, fibroblasts and } \\
\text { endothelial cells }\end{array}$ \\
\hline Laminins [80] & $\begin{array}{l}\text { Major components of basement } \\
\text { membranes underlying epithelial } \\
\text { and endothelial cells and } \\
\text { embedding Schwann, muscle and } \\
\text { fat cells }\end{array}$ & $\begin{array}{l}\text { Heterotrimers of one } \beta \text {, one } \alpha \text { and } \\
\text { one } \gamma \text { chain, which represent } \\
\text { different gene products }\end{array}$ & $\begin{array}{l}\text { Self-assembly and binding to several } \\
\text { matrix proteins and integrins }\end{array}$ \\
\hline Vitronectin [84] & $\begin{array}{l}\text { Regulates clot formation and } \\
\text { immune response, provides } \\
\text { biological cues for cell adhesion, } \\
\text { migration and proliferation and } \\
\text { extracellular anchoring }\end{array}$ & $\begin{array}{l}\text { In human blood is found as a single } \\
\text { chain or as a dimer while in the } \\
\text { extracellular matrix exists as a } \\
\text { disulfide-linked vitronectin } \\
\text { multimer }\end{array}$ & $\begin{array}{l}\text { Multi-domain protein with an RGD } \\
\text { motif to mediate the attachment and } \\
\text { spreading of cells and binding motifs } \\
\text { for collagen, heparin, plasminogen, } \\
\text { glycosaminoglycan and fibrin } \\
\text { binding motifs }\end{array}$ \\
\hline Keratin $[88,185]$ & $\begin{array}{l}\text { Structural protein in the } \\
\text { cytoskeletons of vertebrate } \\
\text { epithelial cells and epidermis } \\
\text { appendages such as hair, nails } \\
\text { and wool }\end{array}$ & $\begin{array}{l}\text { Formed by } \alpha \text {-helical coiled-coil } \\
\text { dimers assembled into } 10 \mathrm{~nm} \text { wide } \\
\text { filaments }\end{array}$ & $\begin{array}{l}\text { Biocompatibility, good cell } \\
\text { attachment and growth }\end{array}$ \\
\hline Silk $[93,98]$ & $\begin{array}{l}\text { Building element of many } \\
\text { arthropod nests, cocoons and } \\
\text { prey traps }\end{array}$ & $\begin{array}{l}\text { Highly repetitive core domain of } \\
\text { alternating poly-A hydrophobic and } \\
\text { G rich hydrophilic motifs }\end{array}$ & $\begin{array}{l}\text { Self-assembly and remarkable } \\
\text { mechanical properties }\end{array}$ \\
\hline $\begin{array}{l}\text { Mussel adhesive proteins } \\
\text { (MAPs) [119] }\end{array}$ & Substrate adhesion & $\begin{array}{l}\text { Repetitive sequence, with molecular } \\
\text { weights ranging between } 5 \text { and } \\
120 \mathrm{kDa} \text { and high presence of } \\
\text { 3,4-dihydroxyphenyl-L-alanine } \\
\text { (DOPA) }\end{array}$ & $\begin{array}{l}\text { Function over a wide range of } \\
\text { temperatures, humidity and salinity } \\
\text { and form permanent bonds to a wide } \\
\text { variety of surfaces }\end{array}$ \\
\hline
\end{tabular}

myriad of biopolymers present in nature, proteins are considered to be one of the most sophisticated groups in terms of chemistry [26]. Therefore some proteins with potential use in the biomedical field will be addressed in the next paragraphs. Table 1 addresses some of the basic features of the animal proteins described in this section.

Collagen is synthesized by fibroblasts and other cell types such as chondrocytes [27] and osteoblasts [28] and is the most abundant protein in the mammalian body, accounting for $20-30 \%$ of the total protein [29]. Its primary functions in tissues are to provide mechanical support [30] and to control cell adhesion, cell migration and tissue repair [31]. Collagens form a large family of triple helical molecules with about 28 different types described [32]. All collagens share the same triple-helical structure where three parallel polypeptides, $\alpha$-chains, coil around each other forming a right handed triple helix chain. In animals these collagen triple helices are known as tropocollagen and its hierarchical organization into more complex structures generates the fibers and networks in tissues such as bone, skin tendons, basement membranes and cartilage $[33,34]$. Collagen is easy to modify and process and its abundance, nonantigenicity, biodegradability, biocompatibility and plasticity make collagen a promising biopolymer for applications in the medical and pharmaceutical fields and tissue engineering purposes [30]. Reconstituted gels of type I collagen are widely used for biomedical applications and its main sources are animal tissues such as skin and tendons [25,35]. Collagen scaffolds have been extensively used for soft tissue repair [36], vascular [37] and dermal tissue engineering [38,39], bone repair [40] and as a carrier for the delivery of drugs [41] and biologically active molecules [42]. Additionally, collagens can also be used to fabricate microspheres for cell encapsulation [43] and drug loading for controlled release [44].

However, despite the wide range of applications collagens matrices lack the mechanical properties required for hard tissue during initial implantation. For this reason collagen is often blended with other materials, either synthetic [45] or natural [46], to overcome mechanical limitations [12].

Fibronectin is also a component of the extracellular matrix with important functions such as structural support 
and signalling for cell survival, migration, contractility, differentiation and growth factor signalling [47]. Fibronectin is synthesized by different cell types, such as fibroblasts and is secreted as a dimer with disulfide bonds formed between 230 and $270 \mathrm{kDa}$ subunits. These subunits are formed by three types of repeating modules named type I, II and III [48]. Fibronectin is a multi-domain glycoprotein with a remarkable number of biological functions, many of which are mediated through interactions with integrins, such as via the RGD sequences present in fibronectin. Besides binding to cell integrins, fibronectin binds to other biologically important molecules such as heparin, collagen/gelatin and fibrin [49]. Since fibronectin is biocompatible and easily recognized by cell integrins, the use of fibronectin or domains of the protein to functionalize scaffolds for tissue engineering is often considered [50]. Polymeric scaffolds of chitosan [51,52], collagen [53] and hyaluronic acid [54] have been modified with fibronectin to improve cell adhesion and proliferation.

Additionally, fibronectin-mimetic peptide-amphiphiles were used in the fabrication of nanofibers and gels with excellent cell adhesion properties [50]. Another strategy was to prepare fibronectin-terminated multilayer films of poly-lysine and dextran sulfate for the study of the spreading behaviour of human umbilical vein endothelial cells. The cells spread to a greater extent and in a more symmetric manner on the films coated with fibronectin, suggesting that such fibronectin coated films may represent a promising strategy to control cell interactions with the materials in tissue engineering [55].

Together with collagen and fibronectin, elastin is also part of the core architecture supporting cell adhesion and growth [56]. Elastin fibers are mainly present in connective and vascular tissues, the lungs and skin. Elastin is a polymer of tropoelastin monomeric precursor and elastin fibers are an important component of the extracellular matrix to impart elasticity to organs and tissues. Hydrophobic domains present in the elastin sequence are responsible for these elastic properties [57,58]. Elastin also has chemotactic activity, inducing cell proliferation and regulating cell differentiation, with the specific binding of integrin $\alpha_{v} \beta_{3}$ to the C-terminus in tropoelastin [59]. Due to its characteristics elastin is of interest for drug delivery and tissue engineering and has been used in the fabrication of hybrid materials in combinations with collagen [60], polycaprolactone (PCL) [61] and silk [62] for the production of vascular grafts [63], hydrogels [64], bone repair [65] and for drug delivery [66]. However, the crosslinking that occurs between the water-soluble tropoelastin monomers to form the insoluble and stable elastin fibers limits the use of elastin from animal origin [56]. Therefore artificial proteins incorporating elastin-like peptides have been of interest for the development of new protein-based biomaterials $[67,68]$ with properties similar to native elastin [69].

Fibrin is another example of a specialized extracellular matrix protein with potential application for tissue engineering. However, unlike collagen, elastin and fibronectin, fibrin networks form mostly during blood clotting. Fibrin is the result of fibrinogen polymerization in the presence of thrombin [70]. Fibrinogen is a $340 \mathrm{kDa}$ protein present in plasma formed by pairs of three different polypeptides, $A \alpha$, $\mathrm{B} \beta$ and $\gamma$, held together by disulfide bridges [71]. Fibrin and fibrinogen are two important components in blood clotting, fibrinolysis, cellular and matrix interactions, inflammation, wound healing and neoplasia [72]. In the particular case of clot formation, thrombin cleavage both $A \alpha$ and $B \beta$ chains at their $\mathrm{N}$-termini, leading to the exposure of polymerization sites in both chains [73]. Subsequently the combination of these polymerization sites leads to the formation of doublestrand twisted fibrils. These fibrin protofibrils undergo lateral aggregation and form branches, producing a three dimensional network [74]. Blood clots are further stabilized by covalent bonds formed by the plasma transglutaminase, factor XIII, making the clot more mechanically stable and less susceptible to enzymatic digestion [75]. Fibrin is a viscoelastic polymer and is used clinically as a medical adhesive; fibrin sealants are FDA approved. Furthermore, fibrin is also used for skin repair, replacing sutures and staples in fixation of skin grafts promoting a better wound healing [76], and in the transplantation of keratinocytes in burned patients [35]. Fibrin is also a promising biopolymer for applications in tissue engineering, in the repair of damaged tissues [77,78], and drug delivery, as a carrier for growth factors [79].

Additionally, two proteinaceous components of the extracellular matrix, laminins and vitronectin, are mainly used to coat synthetic and natural polymer-based materials to improve cellular response. Laminins are cell adhesion glycoproteins localized in the extracellular matrix of the basement membrane and are able to bind to other matrix proteins [80]. Recently, lamimin-derived peptides have been used as coatings to induce the adhesion of different cell types such as hepatocytes [81] and human dermal fibroblasts [82]. Also, these peptides are being studied for drug delivery in the development of targeting drugloaded systems for cancer treatments [83]. Vitronectin is a multifunctional glycoprotein present in the extracellular matrix where it binds to glycosaminoglycans, collagen, plasminogen and urokinase-receptor and its RGD allows it to mediate the adhesion and spreading of cells [84]. This multipartner binding makes vitronectin an attractive biopolymer for tissue engineering and to induce cell attachment when used as a surface coating $[85,86]$.

The proteins described above are extracellular matrix proteins and have been more commonly used for tissue engineering and regenerative medicine applications. However, in the past few years other proteins have also emerged as potential biopolymers for the fabrication of new biomaterials, such as keratin [87]. Moreover, since it is a protein shared by all mammals with a highly conserved amino acid sequence it is expected to offer good cell and tissue responses [88]. Keratin fibers are hierarchically structured proteins present in hard and filamentous structures, such as hairs, horns and nails [87]. The presence of a LDV cell binding domain in keratin amino acid sequence [87] suggests utility for the fabrication of scaffolds for tissue engineering. Keratin based biomaterials have been used to support adhesion, spread and growth of L929 fibroblast cells [89], and the growth and differentiation of osteoblasts (MC3T3-E1) [90]. Keratin films have an inhibitory effect on the IgE receptor-stimulated histamine release from mast 
cells, making it suitable for use in antiallergenic materials [91].

As collagen and keratin, silk is another example of a hierarchically structured fibrous protein. Silk is characterized by its outstanding mechanical properties out-competing high performance man made fibers such as Kevlar, nylon and high-tensile steel, and by its self-assembly leading to fibers with a complex hierarchical arrangement [26]. Silk-protein-based fibers are produced by insects [92] and spiders [93] which use it for different ends such as cocoon and nest construction. However, despite the multitude of functions and different protein structures, many silk-based fibers have similar amino acid compositions and high levels of crystallinity. Silkworm silk produced by the silkworm species Bombyx mori is the most well studied silk protein [92]. The silk fiber is formed by two microfilaments embedded in glue-like glycoproteins named sericin which works as a coating. Each microfilament results from the assembly of a hydrophobic $\sim 370 \mathrm{kDa}$ heavy-chain fibroin protein, a relatively hydrophilic $\sim 25 \mathrm{kDa}$ light-chain fibroin and a $30 \mathrm{kDa}$ P25 protein [94]. Spider dragline silk has a slightly different structure with a core filament formed by two spidroin molecules, major ampullate spidroin protein 1 (MaSp1) and 2 (MaSp2), coated by glycoproteins and lipids [95]. The remarkable mechanical features of the different types of silk are in part due to the presence of $\alpha$-helix and $\beta$-turns, responsible for its elastic properties. These elastic domains alternate with $\beta$-sheet motifs which confer toughness to silk fibers. The strong molecular cohesion occurring with amide-amide interactions in the $\beta$-sheet crystalline regions is thought to be responsible for the remarkable stiffness of silk fibers [96]. In $B$. mori silk, the hexapeptide repeat GAGAGS is involved in the formation of the $\beta$-sheets. In spider silk besides GA sequences there are also poly-Ala blocks and both motifs contribute for the formation of anti-parallel $\beta$-sheets [96]. These poly-A and GA motifs are embedded in amorphous regions formed by either GGX (X can be Tyr, Leu or Gln) or GPGXX motifs believed to be responsible for the elastic features [97]. The outstanding mechanic features and biocompatibility are reasons why silk has been used through the millennia in such diverse applications as hunting, fabrication of paper, wound dressing, textiles and sutures [98]. With new technologies in the fields of polymer synthesis and processing, silk continues to be an important topic of research for biomaterial and biomedical research. In the case of $B$. mori silk, sericulture provides the product used by the textile industry and in medical sutures [93]. Additionally, this silk is being studied for tissue engineering in the form of scaffolds for a range of tissue needs, such as corneal regeneration $[99,100]$, cartilage repair [101,102], vascular grafts $[103,104]$, bone regeneration $[105,106]$ and drug delivery $[107,108]$. As mentioned above $B$. mori silk is available in large supplies from sericulture, and is therefore most commonly used for the above studies. In the case of spiders, it is difficult to breed spider species due to their cannibalistic behaviour. With the advance of biotechnology tools it is now possible to bioengineer spider silk genes to produce spider silk-like proteins [109], such as for tissue engineering [110], cell culture [111], nerve regeneration $[112,113]$ and wound dressings [114].
Mussel adhesive proteins (MAPs) are produced by marine mussels and used in the formation of the byssal threads which allow the animal to anchor to substrates. A common feature to all the adhesives produced by mussels is the presence of the amino acid 3,4-dihydroxyphenyl-Lalanine (DOPA). DOPA residues are key elements for the chemisorption to substrates underwater and the crosslinking process within the adhesive molecules [115]. These natural adhesives display outstanding properties in terms of function under harsh marine environments with wide temperature, salinity and humidity fluctuations and the mechanical effects of tides, waves and currents [116]. These remarkable properties make MAPs attractive biomaterials as bioadhesives. MAPs have been used as bioadhesives for cells [117] and as self-adhesive micro-encapsulated drug carriers for biotechnological, tissue engineering and biomedical applications [118]. MAP derivatives were also used in the fabrication of adhesive-coated meshes as wound sealants, replacing tradition sutures, staples and tacks [119].

The proteins addressed above are widely used for tissue engineering and biomedical applications and can be obtained from animal sources. Moreover, the majority of proteins used in the development of new scaffolds for tissue engineering are extracted from natural sources. In this way, in most cases these polymers need further modifications to make them more suitable for different biomedical applications. The next section refers to physical and chemical approaches used for the functionalization of these biomaterials.

\section{Techniques for the functionalization of protein-based biomaterials}

The properties of protein-based biomaterials can be improved by combining them with bioactive molecules to enhance in vitro and/or in vivo functions. The surface of protein-derived scaffolds can be modified by physical adsorption, physical entrapment (encapsulation) or by chemical modification. These techniques are commonly used to functionalize protein-based biomaterials with different biologically active molecules, such as growth factors and antibiotics, improving cell and tissue responses.

Physical adsorption is a simple immobilization procedure and is frequently used to attach bioactive molecules such as extracellular matrix proteins or growth factors to the surface of scaffolds by dip coating [120]. Adsorption efficiency is dependent on the physical and chemical properties of the material, including wettability, surface topography, functional groups, $\mathrm{pH}$ and electrical charge, among other factors [121]. Many biomaterials are hydrophobic, therefore, methods are needed to enhance wettability to make them more hydrophilic. Physical methods such as bombardment with ions, UV light and plasma modification are used to disrupt chemical bonds between carbon and non-carbon atoms generating unsaturated bonds and radicals which react with oxygen, increasing hydrophilicity and enhancing reactivity towards biological molecules [121]. Natural polymers have the advantage of being rich in reactive chemical groups (hydroxyl, carboxyl, amide) which make them more hydrophilic and 
Table 2

Summary of protein based scaffolds functionalized with different bioactive molecules.

\begin{tabular}{|c|c|c|c|c|}
\hline Protein matrices & Modification process & Modifying molecule & Application & References \\
\hline \multirow[t]{9}{*}{ Collagen } & \multirow[t]{3}{*}{ EDC/NHS covalent immobilization } & VEGF & Vascularisation/angiogenesis & {$[186,187]$} \\
\hline & & FGF/VEGF & Vascularisation/angiogenesis & [188] \\
\hline & & Heparin & BMP/FGF/PDGF delivery system & [189-191] \\
\hline & \multirow[t]{2}{*}{$\begin{array}{l}\text { Traut's reagent and sulfo-SMCC } \\
\text { covalent immobilization }\end{array}$} & $\begin{array}{l}\text { Poly-Histidine } \\
\text { antibody }\end{array}$ & BMP delivery system & {$[192]$} \\
\hline & & VEGF & Vascularisation/angiogenesis & [193] \\
\hline & \multirow[t]{2}{*}{ Adsorption } & BMP-2 & BMP delivery system & [194] \\
\hline & & FGF & $\begin{array}{l}\text { Cartilage regeneration/Growth factor } \\
\text { delivery }\end{array}$ & {$[195,196]$} \\
\hline & \multirow[t]{2}{*}{ Microsphere encapsulation } & BMP-7 & BMP delivery system & [197] \\
\hline & & VEGF & Vascularisation/angiogenesis & [198] \\
\hline \multirow[t]{7}{*}{ Gelatin } & EDC covalent immobilization & TGF-beta & Cartilage regeneration & [199] \\
\hline & \multirow[t]{3}{*}{ Adsorption } & TGF-beta/IGF & Cartilage regeneration & [200] \\
\hline & & FGF & Growth factor delivery & [195] \\
\hline & & Fibronectin & Cartilage regeneration & [201] \\
\hline & \multirow[t]{3}{*}{ Microsphere encapsulation } & TGF-beta & Chondrogenesis/cartilage regeneration & {$[202,203]$} \\
\hline & & BMP-2/VEGF & Angiogenesis and osteogenesis & [204] \\
\hline & & BMP-2 & Growth factor delivery & [205] \\
\hline \multirow[t]{3}{*}{ Fibrin } & \multirow[t]{2}{*}{ Microsphere encapsulation } & FGF & Angiogenesis & {$[206]$} \\
\hline & & BMP-2 & Bone regeneration & {$[207,208]$} \\
\hline & Patterning immobilization & FGF-2 & Tissue engineering & [209] \\
\hline \multirow[t]{2}{*}{ Heparin } & \multirow[t]{2}{*}{ Michael type addition } & BMP-2 & Bone/ligament regeneration & [210] \\
\hline & & HGF & Hepatocyte differentiation & [211] \\
\hline \multirow[t]{9}{*}{ Silk } & Cyanuric chloride immobilization & Lactose & Hepatocyte attachment & [212] \\
\hline & Crosslinking & Gelatin & Tendon tissue engineering & {$[213]$} \\
\hline & \multirow{5}{*}{ Adsorption } & FGF & Growth factor delivery & [124] \\
\hline & & Gelatin & Drug/growth factor delivery & {$[214]$} \\
\hline & & $\begin{array}{l}\text { Collagen/chodroitin-6- } \\
\text { sulfate/hyaluronan }\end{array}$ & Tendon tissue engineering & {$[215]$} \\
\hline & & Collagen & Tendon tissue engineering & {$[216,217]$} \\
\hline & & BMP-2 & Bone regeneration & {$[218]$} \\
\hline & Microsphere encapsulation & IGF & Drug/growth factor delivery & [219] \\
\hline & Blend & Gelatin & Tissue engineering & [220] \\
\hline Silk/collagen & Adsorption & SDF-1 & Tendon tissue engineering & [221] \\
\hline
\end{tabular}

capable of interacting with bioactive molecules. Collagen and silk are examples of protein-based materials that have been functionalized through adsorption of bioactive molecules, including bone morphogenetic proteins (BMPs) [122,123], basic fibroblast growth factor (bFGF) [124], vascular endothelial growth factor (VEGF) [125] and therapeutic compounds such as antibiotics [126] and heparin [127] as it is summarized in Table 2. In most of these studies the protein-based scaffolds were soaked in a solution containing the bioactive component. In other cases the proteins were blended with the bioactive molecule in solution and then cast to form scaffolds [128].

Since adsorption is based on relatively weak or moderate electrostatic, van der Waals, hydrogen and hydrophobic interactions the binding stability of the adsorbed molecules can vary depending on environmental conditions. In this way, changes in $\mathrm{pH}$, ionic strength and adsorbed species concentration of the surrounding medium can result in an uncontrolled release of the immobilized species [120]. For example, bone morphogenetic proteins (BMPs) tend to diffuse away from the fracture area and high doses are required to induce the desired osteogenic response. The release profile of BMP-2 from collagen sponges shows an initial burst during the first $10 \mathrm{~min}$, where the carrier loses around $30 \%$ of the BMP-2, followed by slow release during the next 3-5 days. This initial burst release can cause clinical complications, such as ectopic bone formation, soft tissue hematomas and bone resorption [129,130].
To overcome these issues, covalent immobilization has been widely used since it has the advantage of providing stable attachment of bioactive agents to polymeric scaffolds. With proper design, covalent conjugation has proven to be a very effective strategy to control the release profile of the immobilized agent since these molecules are retained for longer time periods at the delivery site, when compared with adsorption [11]. Carbodiimide coupling is broadly used in protein chemistry to react activated surface carboxylic acid groups from protein-based scaffolds with the amines present on the peptide or protein to be immobilized $[131,132]$. Carboxylic groups are activated by using 1-ethyl-3-(3-dimethylaminopropyl)-carbodiimide (EDC) mixed with either N-hydroxysuccinimide (NHS), dicyclohexyl-carboiimide (DCC) or carbonyl diimidazole (CDI) $[131,132]$. This basic protein chemistry has been extensively used to immobilize molecules as it is shown in Table 2, including BMPs and RGD peptides onto silk and collagen scaffolds. A drawback of this coupling method is the difficulty in characterizing the new peptide-protein scaffolds, due to the background noise from the protein scaffold itself, making it difficult to measure the signal coming from the small amount of peptide immobilized on the scaffold surface in order to quantify how much peptide was immobilized [132]. Another drawback can be the presence of reactive amine groups aside from the $\mathrm{N}$-terminal amine. These reactive side groups need to be protected, followed by deprotection after the coupling 
chemistry is carried out, although the use of harsh conditions can affect the biological activity of the immobilized molecules [131].

Glutaraldehyde, polyethylene glycol diacrylate and hexamethylene diisocyanate can be used to bridge the amine groups present in the peptide or protein to be immobilized and in the protein based scaffolds [132,133]. Glutaraldehyde has been used to couple insulin [134] and lipase [135] onto silk scaffolds and to crosslink blends of collagen and silk [136]. However, the potential release of toxic residual molecules formed during the crosslinking process is a concern if these biomaterials are to be used for biomedical applications [133].

Encapsulation of bioactive molecules within protein matrices has also been explored as a method to control the release of bioactive agents. In many cases chemical modifications are required in order to have better control over the release profile of the encapsulated molecules. Crosslinked gelatin microspheres later impregnated with basic fibroblast growth fact (bFGF) and loaded into collagen sponges were used in order to have controlled release of bFGF at a defect site [137] (Table 2). Furthermore, crosslinked collagen microspheres loaded with bovine serum albumin (BSA) and nerve growth factor were prepared and release profiles assessed [44]. In both studies collagen microspheres had to be crosslinked in order to reduce the initial burst and attain better control of protein release. EDC and NHS were also used as coupling reagents to covalently bind 2,3-dihydroxybenzoic to gelatin microspheres, which were incorporated into a reconstituted collagen scaffold for a wound dressing [138]. Silk microspheres were used for the encapsulation of bioactive proteins and other molecules, exploiting the self-assembly properties of silk to control the release profile [139].

Many formulations and delivery strategies have been explored in order to achieve functionalization and sustained release of different molecules. However, in the particular case of bioactive proteins loaded into proteinbased scaffolds, protein structure and topology must be considered in order to prevent protein denaturation, as a consequence of the adsorption or immobilization processes, and protein aggregation during the release period which can result in the loss of bioactivity $[11,140]$. Proteins in denatured forms are often antigenic and can induce immunogenic reactions with negative clinical consequences [140].

Most of the methods being used for functionalization of polymeric structures and drug release have some disadvantages and new strategies are clearly needed. Advances in the fields of self-assembly and biotechnology, mainly via recombinant DNA approaches, can offer some important options to address the deficiencies noted above, to help in the development of the next generation of biomaterials. The importance of recombinant DNA technology for the development of new protein based biomaterials will be the focus of the next section.

\section{Recombinant proteins for tissue engineering}

Since mammalian tissues are the main source of materials such as collagen, gelatin, fibrin and elastin there are concerns with disease transmission and immunogenic responses in in vivo studies, as well as batch-to-batch variability $[19,141]$. To overcome these limitations, peptide synthesis and recombinant DNA protein methodologies have been explored. Chemical synthesis can be a quick and efficient method to fabricate short peptides in relatively small quantities [142]. However, the synthesis of peptide sequences with more than $35-40$ amino acids is not feasible due to a drop in yield and efficiency paralleled by an exponential increase in cost [143]. Recombinant DNA technology provides well established protocols for cloning, mutation and gene fusion in different host cells for the expression of peptides and proteins with a broad range of sizes [144]. Furthermore, the increased efficiency in making synthetic oligonucleotides and the use of standardized kits and protocols for cloning and protein expression make the transgenic production approach more cost-effective for large scale protein production [144]. Besides engineering biological components already present in nature as shown in Table 3, the field of synthetic biology is also focused on the design of new peptides and protein sequences. This can be achieved by establishing new artificial self-assembling peptides or by fusing together different bioactive domains or protein motifs that are not otherwise found together in nature. Table 4 gives an overview of the studies published during the past few years using this approach [144]. Since genetic engineering offers the possibility of altering the amino acid sequence of the expressed protein by adding or substituting codons, it is possible to generate alternative sequences with tunable properties that can be used as promising biomaterials for medical applications.

Below we will address some of the proteins that have been effectively cloned and expressed in different recombinant systems. The potential of genetic engineering to be used as a tool for the functionalization of biopolymers with different bioactive peptides through the synthesis of new fusion proteins will also be discussed.

Collagen has been cloned and expressed in recombinant systems (Table 3). The use of recombinant collagen has benefits since it can be a safe product with useful self-assembly features [144] and the possibility of being functionalized with bio-instructive domains [19] such as cell adhesion ligands [141]. Over the past 20 years recombinant systems for the large scale-production of recombinant collagen have been developed and optimized. Recombinant collagen has been expressed in mammalian cells, insect cells, Escherichia coli, transgenic tobacco, mice and silkworm [145]. From these recombinant hosts only the mammalian cells expressed collagen with 4-hydroxyproline content identical to native collagen. However, since the level of protein production was low $(0.6-20 \mathrm{mg} / \mathrm{L})$ this system was not commercially viable [146]. Since the production cost in yeast and $E$. coli is much lower than in mammalian cell culture, a multigene expression technology was adopted in order to overcome the absence of the enzyme prolyl 4-hydroxylase, an essential element in the synthesis of fully hydroxylated collagens [146]. The absence of this enzyme leads to non-triple-helical and non-functional collagen molecules, which are unstable below physiological temperatures and thus unsuitable for medical applications. Hence, the multigene expression approach based on the 
Table 3

Biopolymers expressed in recombinant systems and their potential uses.

\begin{tabular}{|c|c|c|c|}
\hline Protein & Expression system & Advantages/applications & References \\
\hline \multirow[t]{8}{*}{ Collagen I } & Transgenic corn & Food and pharmaceutical industries & {$[222]$} \\
\hline & Yeast Pichia pastoris & $\begin{array}{l}\text { Identical } 4 \text {-hydroxyproline content to human } \\
\text { collagen; medical applications such as corneal } \\
\text { replacement }\end{array}$ & {$[147,150,223]$} \\
\hline & Yeast Saccharomyces cerevisiae & Study of collagen expression and maturation & {$[224,225]$} \\
\hline & Mammalian HT1080 cells & $\begin{array}{l}\text { Optimization of recombinant collagen } \\
\text { expression and isolation methodology }\end{array}$ & {$[226,227]$} \\
\hline & Insect cells & $\begin{array}{l}\text { Optimization of recombinant collagen } \\
\text { expression and isolation methodology; } \\
\text { Structural studies }\end{array}$ & {$[228,229]$} \\
\hline & Mammalian, mouse milk & $\begin{array}{l}\text { Optimization of recombinant collagen } \\
\text { expression }\end{array}$ & {$[230,231]$} \\
\hline & E. coli JM109 strain & $\begin{array}{l}\text { Large quantities production/therapeutic, } \\
\text { biomaterial, or bioengineering applications, }\end{array}$ & {$[232]$} \\
\hline & E. coli & Bone tissue engineering & {$[151]$} \\
\hline \multirow[t]{2}{*}{ Collagen II } & Yeast Pichia pastoris & $\begin{array}{l}\text { Identical 4-hydroxyproline content to human } \\
\text { collagen }\end{array}$ & {$[147]$} \\
\hline & Insect cells & $\begin{array}{l}\text { Optimizing recombinant collagen expression } \\
\text { systems }\end{array}$ & {$[233]$} \\
\hline \multirow[t]{4}{*}{ Collagen III } & Yeast Pichia pastoris & $\begin{array}{l}\text { Higher production level; identical } \\
\text { 4-hydroxyproline content to human collagen; } \\
\text { scientific and medical applications such as } \\
\text { corneal replacement }\end{array}$ & {$[147,150,234]$} \\
\hline & Yeast Saccharomyces cerevisiae & $\begin{array}{l}\text { Optimizing recombinant collagen expression } \\
\text { systems }\end{array}$ & {$[235]$} \\
\hline & Insect cells & $\begin{array}{l}\text { 4-Hydroxyproline content similar to human } \\
\text { collagen; study of collagen chain association } \\
\text { and folding }\end{array}$ & {$[236,237]$} \\
\hline & Silkworm & $\begin{array}{l}\text { Viable expression system for bulk protein } \\
\text { expression }\end{array}$ & {$[238]$} \\
\hline Collagen V & Mammalian cells & Structural studies & [239] \\
\hline Collagen VI & Mammalian cells & Collagen and heparin binding studies & {$[240]$} \\
\hline Collagen VII & Mammalian cells & $\begin{array}{l}\text { Study of dystrophic epidermolysis genetic } \\
\text { disorder }\end{array}$ & {$[241]$} \\
\hline Collagen X & Mammalian HEK293 cells & $\begin{array}{l}\text { Optimizing recombinant collagen expression } \\
\text { systems }\end{array}$ & {$[242]$} \\
\hline Collagen XI & E. coli BL21 & Study the regulation of collagen fibrillogenesis & [243] \\
\hline Collagen-like protein & Mammalian HT1080 cells & Biomedical applications & {$[152,244]$} \\
\hline Gelatin-like proteins & Yeast Pichia pastoris & Biomedical applications & [245] \\
\hline \multirow[t]{3}{*}{ Elastin-like peptides } & Yeast Pichia pastoris & Optimizing cloning and expression process & [246] \\
\hline & E. coli strain BL21-Gold & $\begin{array}{l}\text { Vascular replacement; tissue engineering, } \\
\text { controlled drug release and cell encapsulation; } \\
\text { biomedical applications }\end{array}$ & {$[167,247-253]$} \\
\hline & E. coli BLR strain & Biomedical applications & {$[254]$} \\
\hline \multirow{5}{*}{$\begin{array}{l}\text { Spider silk major ampullate } \\
\text { from Nephila clavipes }\end{array}$} & E. coli RY-3041 & Structural studies/biomedical applications & {$[255,256]$} \\
\hline & E. coli SG 13009pREP4 & Structural studies/biomedical applications & [155] \\
\hline & E. coli BL21 & Structural studies/biomedical applications & {$[257-259]$} \\
\hline & E. coli M109 strain & Structural studies/biomedical applications & [260] \\
\hline & Yeast Pichia pastoris & Structural studies/biomedical applications & {$[158]$} \\
\hline $\begin{array}{l}\text { Spider silk major dragline } \\
\text { proteins ADF-3 and ADF-4 } \\
\text { from Araneus diadematus }\end{array}$ & E. coli BLR strain & Structural studies/biomedical applications & [157] \\
\hline $\begin{array}{l}\text { Spider silk flagelliform from } \\
\text { Nephila clavipes }\end{array}$ & E. coli BL21 strain & Structural studies/biomedical applications & {$[156]$} \\
\hline $\begin{array}{l}\text { Spider silk like proteins - NcDS, } \\
\text { (SpI)7 and [(SpI)4/(SpII)1]4 }\end{array}$ & E. coli BL21 strain & Structural studies/biomedical applications & {$[261]$} \\
\hline \multirow[t]{2}{*}{ Fibrinogen } & Mammalian cells & Fibrin sealant & {$[262]$} \\
\hline & Yeast Pichia pastoris & Fibrin sealant & {$[263]$} \\
\hline Fibronectin & E. coli & Cell adhesion & {$[264,265]$} \\
\hline
\end{tabular}

co-expression of procollagen polypeptide chains and $\alpha$ and $\beta$-subunits of proyl 4-hydroxylase using the yeast, Pichia pastoris, was developed [147]. Collagen types I, II and III were expressed with a 4-hydroxyproline content identical to the native human proteins and expression levels of $0.2-0.6 \mathrm{~g} / \mathrm{L}$ in $2 \mathrm{~L}$ bioreactors were achieved [147]. The use of recombinant collagen as a gel has been reported for chondrocytes [148], as a microcarrier [149], as corneal substitutes [150] and for bone regeneration applications [151]. Furthermore, customized collagen-like peptides formed with tandem repeats of the D4 domain of human collagen type II, a critical sequence for supporting the migration of chondrocytes, were also reported [140]. Chondrocytes seeded on polyglycolic acid scaffolds coated with this 
Table 4

New chimeric proteins with potential application in the biomedical field.

\begin{tabular}{|c|c|c|c|}
\hline Fusion protein & Expression system & Applications & References \\
\hline $\begin{array}{l}\text { R136K (FGF-1 mutant) + collagen } \\
\text { biding domain }\end{array}$ & E. coli BL21 (pLysS) strain & $\begin{array}{l}\text { Selective binding to collagen and potent } \\
\text { angiogenic, mitogenic and chemotactic activity } \\
\text { for endothelial cells }\end{array}$ & {$[266,267]$} \\
\hline VEGF + collagen biding domain & E. coli BL21 strain & Improve diabetic wound healing & [268] \\
\hline FGF + fibronectin cell binding domain & E. coli JM109 strain & $\begin{array}{l}\text { Stimulates angiogenesis, biomedical } \\
\text { applications/tissue engineering }\end{array}$ & [269] \\
\hline FGF + collagen binding domain & E. coli BL21strain & $\begin{array}{l}\text { Delivery systems/biomedical } \\
\text { applications/tissue engineering }\end{array}$ & {$[270]$} \\
\hline $\begin{array}{l}\text { FGF + glutathione S-transferase } \\
\text { (GST-bFGF) }\end{array}$ & E. coli & $\begin{array}{l}\text { Stimulate the growth of human umbilical vein } \\
\text { endothelial cells }\end{array}$ & {$[271]$} \\
\hline FGF2 + fibronectin (FGF2-FNIII9-10) & E. coli TOP10 strain & Delivery of bioactive molecules & [179] \\
\hline $\mathrm{EGF}+$ collagen binding domain & E. coli $\mathrm{BL} 21(\mathrm{DE} 3)$ strain & $\begin{array}{l}\text { Delivery systems/biomedical } \\
\text { applications/tissue engineering }\end{array}$ & {$[270]$} \\
\hline EGF-collagen & Insect cells & Tissue engineering applications & [181] \\
\hline $\begin{array}{l}\mathrm{EGF}+\text { immunoglobulin } \mathrm{G}(\mathrm{IgG}) \mathrm{Fc} \\
\quad \text { region }(\mathrm{EGF}-\mathrm{Fc})\end{array}$ & E. coli BL21 strain & Cell adhesion & {$[272]$} \\
\hline Silk+ elastin (SELP-47 K) & E. coli & $\begin{array}{l}\text { Promote cell attachment and growth/tissue } \\
\text { Engineering }\end{array}$ & [273] \\
\hline Spider silk + dentin matrix protein & E. coli $\mathrm{RY}-3041$ strain & Biomedical applications/tissue engineering & {$[177]$} \\
\hline Spider silk + bone sialoprotein & E. coli $\mathrm{RY}-3041$ strain & Biomedical applications/tissue engineering & {$[176]$} \\
\hline $\begin{array}{l}\text { Spider silk + antimicrobial domain } \\
\text { (HNP-2, HNP-4 and hepcidin) }\end{array}$ & E. coli $\mathrm{RY}-3041$ strain & Biomedical applications/tissue engineering & {$[178]$} \\
\hline Bombyx mori silk + RGD + elastin (FES8) & E. coli BL21 strain & Biomedical applications & {$[274]$} \\
\hline RGDS + silk fibroin (RGDSx2 fibroin) & Silkworm & Facilitate chondrogenesis & {$[275]$} \\
\hline Collagen + GYIPEAPRDGQAYVRKDGEWVLLSTFL & E. coli BL21 strain & $\begin{array}{l}\text { Stabilize the triple helix formed in the } \\
\text { proteins/biomedical applications }\end{array}$ & {$[276]$} \\
\hline BMP-2 + collagen-biding domain & E. coli BL21strain & Bone repair & [277-279] \\
\hline $\begin{array}{l}\text { TGF-B1-F1 and TGF-B1-F2 + collagen } \\
\text { binding domain }\end{array}$ & E. coli & Biomedical applications/tissue engineering & {$[280]$} \\
\hline $\begin{array}{l}\text { hbFGF-F1 and hbFGF-F2 + collagen } \\
\text { binding domain }\end{array}$ & E. coli & Biomedical applications/tissue engineering & {$[281]$} \\
\hline PDGF + collagen binding domain & E. coli BL21 strain & Tissue regeneration and wound repair & {$[282]$} \\
\hline $\begin{array}{l}\text { Fibronectin III7-10 + cadherin } 11 \text { EC } \\
\quad 1-2\end{array}$ & E. coli Rosetta-gami strain & Orthopaedic regeneration & [283] \\
\hline $\begin{array}{l}\text { Fibronectin cell binding domain-EGF } \\
\quad(\mathrm{C}-\mathrm{EGF})\end{array}$ & E. coli HBIOI strain & Drug delivery & {$[180]$} \\
\hline $\begin{array}{l}\text { Fibronectin cell binding domain-EGF } \\
\quad \text { (FNCBD-EGF) }\end{array}$ & E. coli & $\begin{array}{l}\text { Skin wounds, catheter-injured arteries, and } \\
\text { hind limb muscles }\end{array}$ & {$[284]$} \\
\hline $\begin{array}{l}\text { RGD/EGF/hydrophobic sequence E12 } \\
\text { (ERE-EGF) }\end{array}$ & E. coli & Controlling cell functions & {$[285]$} \\
\hline NGF- $\beta+$ collagen binding domain & E. coli BL21strain & $\begin{array}{l}\text { Delivery system for neuronal development and } \\
\text { regeneration }\end{array}$ & {$[286]$} \\
\hline
\end{tabular}

collagen-like protein formed cartilaginous constructs with superior properties to the scaffolds coated with native type II collagen [152]. These advances highlight the importance of recombinant DNA technology in the synthesis of proteins with applications that until now have only been available from animal sources.

Recombinant DNA technology was particularly advantageous in the expression of large and repetitive proteins such as silk. As in the case of collagen, different expression hosts have been explored for the biosynthesis of spider silk (Table 3). Major ampullate silk was successfully expressed by bovine mammary epithelial cells, hamster kidney cells, insect cells and in the milk of transgenic goats, generally with low yields [153]. However, bacteria can be grown at large scales and have the advantage of being easier to handle and more cost-effective. Therefore, E. coli has been actively pursued as an expression host for spider silks. Since bacterial hosts have distinct codon usages, silk sequences from different spider species were reverse transcribed into cDNA, using the E. coli codon preferences, and double stranded oligonucleotides coding for different domains of silk proteins were prepared [154]. These double strand oligonucleotides were then assembled into synthetic genes coding for silk proteins [153]. This cloning strategy was employed with successes for the expression of Nephila clavipes consensus sequence for major ampullate silk protein 1 (MaSp1) and MaSp2 [155] and the flagelliform silk protein [156] from the same species. Cloning and expression in E. coli, of both major ampullate silks ADF-3 and ADF-4 from the species Araneus diadematus was also reported (Table 3 ) with yields between 140 and $360 \mathrm{mg} / \mathrm{L}$ [157]. Besides E. coli, other hosts for the cloning and expression of spider silks have also been explored. The yeast $P$. pastoris is considered an attractive host for the expression of recombinant proteins since this expression system is well developed for industrial fermentation, reaching high cell densities using low-cost media. For these reasons it was successfully used for the expression of spider silk dragline using genes of up to 3000 codons with no evidence of truncated synthesis, a common occurrence in E. coli host [158]. Plants such as tobacco and Arabidopsis thaliana are also being explored as transgenic host 


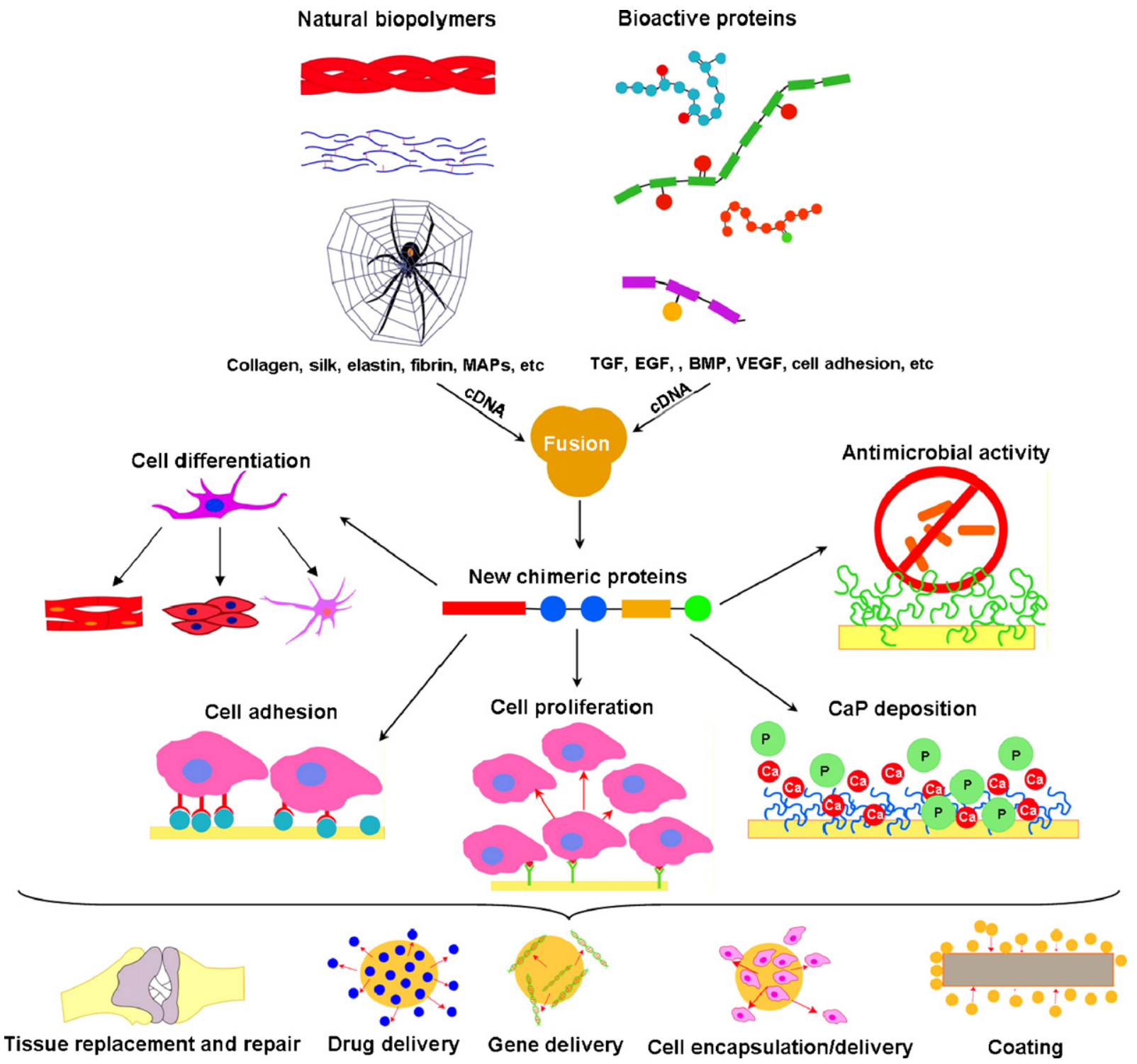

Fig. 1. Scheme highlighting some of the features and applications of chimeric protein-based biomaterials synthesized through recombinant DNA technology.

systems for silk proteins, with yields of $2 \%$ in tobacco leaves, $8.5 \%$ in A. thaliana leaf apoplasts and $18 \%$ in the endoplasmic reticulum of seeds [153]. Similar approaches as above for collagens and silks have been applied to the fabrication of recombinant elastin-like proteins that mimic native elastin (Table 3) [56]. These new protein polymers have a modular structure formed with repeats of the pentapeptide (VP-Xaa-Yaa-G) $n$ where Xaa is either G or A and Yaa can be any residue but $P$. These recombinant elastin-like proteins are capable of reversible temperature-dependant self assembly in aqueous medium [67]. This feature allows for the purification of protein based upon temperatureinduced aggregation. Elastomeric pentapeptides with up to 251 GVGVP repeats were soluble in low ionic solution at temperatures below $25^{\circ} \mathrm{C}$ [159]. Above this temperature the polymer hydrophobically folds into $\beta$-spiral structures that further aggregate due to hydrophobic associations.
These aggregates can then be collected by selective centrifugation. This methodology allows for facile purification [160,161]. Moreover, elastin-like polypeptides (ELPs) can be used as a purification tag. The fusion of ELPs with other proteins exploits the inverse temperature transition of ELPs and provides a simple method for the isolation of a recombinant ELP fusion proteins by cycling the protein solution through the soluble and insoluble phases using inverse transition cycling [162-164]. ELP tags can be cleaved by a $\mathrm{pH}$ shift and removed by a final thermal precipitation [164].

Additionally there is the possibility of amino acid substitutions in the pentapeptide repeats [165] and previous studies have shown that the replacement of $G$ in $(\mathrm{VPGVG})_{n}$ by $\mathrm{A}$ in (VPAVG) ${ }_{n}$ leads to mechanical changes in the protein from elastic to plastic $[67,166]$. The physical crosslinking resulting from this amino acid replacement leads to a more plastic matrix with a Young's modulus 
two orders of magnitude higher than in the case of $(\mathrm{VPGVG})_{n}[166]$. Also, physical crosslinking has advantages over chemical crosslinking since it allows for easy processing, avoids the use of chemical reagents and excludes the need of removing unreacted intermediates [167]. Synthetic amphiphilic block copolymers with distinct block polarity composed of hydrophilic and hydrophobic segments can also be generated [67]. These block copolymers exhibit tunable mechanical and amphiphilic properties dependent on the amino acid substitution. The flexibility of these block copolymer designs extends the range of applications from micelles formed by self-assembly of amphiphilic sequences for drug delivery, to temperature responsive hydrogels for cell encapsulation and coatings of medical devices to improve host responses [168-170]. Genetic engineering also offers the possibility of enriching the sequences of proteins to improve their biological activity by fusing them with other protein motifs with specific bioactivities (Table 4). Initial elastin matrices for cell adhesion showed that cells did not adhere to these biomaterials [171]. RGD and REDV cell adhesion peptide sequences were inserted into the elastins leading to a dramatic increase in cell attachment $[169,170]$. Silk-based block copolymers were also engineered to carry an RGD cell binding domain for intracellular gene delivery. The presence of labelled DNA inside cells was detected by confocal laser scanning microscopy and demonstrates the potential of these silk bioengineered block copolymers as highly tailored gene delivery systems [172]. The addition of a recognition site for an enzyme with proteolytic activity can also be incorporated into the sequences, favouring biomaterials degradation [173]. The fusion of the $N$. clavipes consensus sequence for MaSp1 with proteins such as dentin matrix protein and bone sialoprotein, involved in calcium phosphate deposition in teeth and bone [174,175], respectively, also had positive results from a biomaterials perspective $[176,177]$. In both fusion proteins the silk domain retained its self assembly properties and the dentin matrix protein and bone sialoprotein domains maintained their ability to induce the deposition of calcium phosphates. These results demonstrated the potential of chimeric proteins for applications in tissue engineering and regenerative medicine for the design of new protein-based scaffolds for bone regeneration [176,177].

Furthermore, promising results were also obtained when the $N$. clavipes consensus sequence for MaSp1 was fused with antimicrobial peptides, namely neutrophil defensins 2 and 4 and hepcidin, using a step-by-step cloning methodology [178]. The cloning and expression of these new fusion proteins expanded these chimera or fusion approaches to include antimicrobial-functionalized protein-based biomaterials [178] offering a path forward in reducing the use of antibiotics to prevent infection in implants and in the design of a new generation of proteinbased materials bioengineered to prevent the onset of infections.

Other proteins have also been expressed as fusion proteins with biological activity such as FGF2-FNIII9-10 formed by a fibronectin fragment FNIII9-10 connected to the carboxy terminus of fibroblast growth factor 2 (FGF-2) [179]. Previous studies reported the synergistic effect of fibronectin and FGF-2 on osteoblast adhesion. The FGF2-FNIII9-10 fusion protein showed a significant increase in cell adhesion and proliferation when compared with FNIII9-10 alone [179]. The cell-binding domain of human fibronectin was also fused with epidermal growth factor (EGF), important in tissue regeneration to accelerate wound healing and enhance cell proliferation. The new construct, designated as C-EGF, had both cell-adhesive and EGF activity and the recombinant construct may be an effective drug delivery system for EGF in therapeutic situations [180]. EGF polypeptide was fused with collagen type III and the new construct retained the triple helix of collagen and the mitogenic activity of EGF, suggesting that this protein could be used as a biocompatible, biodegradable and adhesive fibrous mitogen for tissue regeneration [181].

The examples outlined above highlight the potential of synthetic biology in the synthesis of biopolymers for tissue engineering and regenerative medicine (Fig. 1).

\section{Conclusions}

Genetic engineering makes it possible to develop new biopolymers with a complexity and functionality resembling natural polymers formed in nature. By using synthetic DNA it is possible to combine different functional domains for a fusion protein, merging cell adhesion and migration, mechanical properties and antimicrobial factors, towards multifunctional biomaterial systems. This approach eliminates the need to use chemical methodologies for covalent binding of bioactive motifs or crosslinking, which can have drawbacks of protein denaturation and residuals with toxicity. Although there has been a significant progress in exploiting genetic engineering for tissue engineering and regenerative medicine purposes during recent years, there remains a lot to be explored in order to take full advantage of the outstanding potential of genetic engineering to be used as a tool in the development of the next generation of custom-design biomaterials.

\section{Acknowledgements}

Sílvia Gomes thanks the Portuguese Foundation for Science and Technology (FCT) for providing her a $\mathrm{PhD}$ Grant (SFRH/BD/28603/2006). This work was carried out under the scope of the FIND \& BIND project funded by the agency EU-EC (FP7 program), the FCT R\&D project ProteoLight (PTDC/FIS/68517/2006) funded by the FCT agency, the Chimera project (PTDC/EBB-EBI/109093/2008) funded by the FCT agency, the NIH (P41 EB002520) Tissue Engineering Resource Center and the NIH (EB003210 and DE017207).

\section{References}

[1] Tsubouchi M, Matsui S, Banno Y, Kurokawa K, Kawakami K. Overview of the clinical application of regenerative medicine products in Japan. Health Policy 2008;88:62-72.

[2] Laurencin CT, Ambrosio AMA, Borden MD, Cooper JA. Tissue engineering: orthopedic applications. Annu Rev Biomed Eng 1999;1:19-46.

[3] Salgado AJ, Coutinho OP, Reis RL. Bone tissue engineering: state of the art and future trends. Macromol Biosci 2004;4:743-65. 
[4] Younger EM, Chapman MW. Morbidity at bone graft donor sites. J Orthop Trauma 1989;3:192-5.

[5] Weir MD, Xu HH. Osteoblastic induction on calcium phosphate cement-chitosan constructs for bone tissue engineering. J Biomed Mater Res A 2010;94A:223-33.

[6] Wise DL, Trantolo DJ, Lewandrowski K-U, Gresser JD, Cattaneo MV Yaszemski MJ. Biomaterials engineering and devices. Totowa, NJ: Human Press; 2000.

[7] Gunatillake PA, Adhikari R. Biodegradable synthetic polymers for tissue engineering. Eur Cell Mater 2003;5:1-16.

[8] Sokolsky-Papkov M, Agashi K, Olaye A, Shakesheff K, Domb AJ. Polymer carriers for drug delivery in tissue engineering. Adv Drug Deliv Rev 2007;59:187-206.

[9] Mark K.v.d., Park J, Bauer S, Schmuki P. Nanoscale engineering of biomimetic surfaces: cues from the extracellular matrix. Cell Tissue Res 2010;339:131-53.

[10] Williams DJ, Sebastine IM. Tissue engineering and regenerative medicine: manufacturing challenges. IEE Proc Nanobiotechnol 2005;152:207-10.

[11] Biondi M, Ungaro F, Quaglia F, Netti PA. Controlled drug delivery in tissue engineering. Adv Drug Deliv Rev 2008;60:229-42.

[12] George A, Ravindran S. Protein templates in hard tissue engineering. Nano Today 2010;5:254-66.

[13] Kohn J, Welsh WJ, Knight D. A new approach to the rationale discovery of polymeric biomaterials. Biomaterials 2007;28:4171-7.

[14] Bie CD. Genzyme: 15 years of cell and gene therapy research. Regen Med 2007;2:95-7.

[15] Basad E, Ishaque B, Bachmann G, Stürz H, Steinmeyer J. Matrix-induced autologous chondrocyte implantation versus microfracture in the treatment of cartilage defects of the knee: a 2-year randomised study. Knee Surg Sports Traumatol Arthrosc 2010;18:519-27.

[16] Zaulyanov L, Kirsner RS. A review of a bi-layered living cell treatment (Apligraf) in the treatment of venous leg ulcers and diabetic foot ulcers. Clin Interv Aging 2007;2:93-8.

[17] Degim IT, Çelebi N. Controlled delivery of peptides and proteins. Curr Pharm Des 2007;13:99-117.

[18] Nagaoka M, Jiang HL, Hoshiba T, Akaike T, Cho CS. Application of recombinant fusion proteins for tissue engineering. Ann Biomed Eng 2010;38:683-93.

[19] Romano NH, Sengupta D, Chung C, Heilshorn SC. Proteinengineered biomaterials: nanoscale mimics of the extracellular matrix. Biochim Biophys Acta 2010;1810:339-49.

[20] Zelzer M, Ulijn RV. Next-generation peptide nanomaterials: molecular networks, interfaces and supramolecular functionality. Chem Soc Rev 2010;39:3351-7.

[21] Patterson J, Martino MM, Hubbell JA. Biomimetic materials in tissue engineering. Mater Today 2010;13:14-22.

[22] Krishna OD, Kiick KL. Protein- and peptide-modified synthetic polymeric biomaterials. Biopolymers 2010;94:32-48.

[23] Mano JF, Silva GA, Azevedo HS, Malafaya PB, Sousa RA, Silva SS, Boesel LF, Oliveira JM, Santos TC, Marques AP, Neves NM, Reis RL. Natural origin biodegradable systems in tissue engineering and regenerative medicine: present status and some moving trends. J R Soc Interface 2007;4:999-1030.

[24] Silva SS, Mano JF, Reis RL. Potential applications of natural origin polymer-based systems in soft tissue regeneration. Crit Rev Biotechnol 2010;30:200-21.

[25] Chung HJ, Park TG. Surface engineered and drug releasing prefabricated scaffolds for tissue engineering. Adv Drug Deliv Rev 2007;59:249-62.

[26] Heim M, Römer L, Scheibel T. Hierarchical structures made of proteins. The complex architecture of spider webs and their constituent silk proteins. Chem Soc Rev 2010;39:156-64.

[27] Madsen K, Mark K.v.d., Menxel M.v., Friberg U. Analysis of collagen types synthesized by rabbit ear cartilage chondrocytes in vivo and in vitro. Biochem J 1984;221:189-96.

[28] Mansell JP, Yarram SJ, Brown NL, Sandy JR. Type 1 collagen synthesis by human osteoblasts in response to placental lactogen and chaperonin 10, a homolog of early-pregnancy factor. In Vitro Cell Dev Biol Anim 2002;38:518-22.

[29] Harkness RD. Biological functions of collagen. Biol Rev 1961;36:399-463.

[30] Lee CH, Singla A, Lee Y. Biomedical applications of collagen. Int J Pharm 2001;221:1-22.

[31] Kadler KE, Baldock C, Bella J, Boot-Handford RP. Collagens at a glance. J Cell Sci 2007;120:1955-8.

[32] Veit G, Kobbe B, Keene DR, Paulsson M, Koch M, Wagener R. Collagen XXVIII, a novel von Willebrand factor A domain containing protein with many imperfections in the collagenous domain. J Biol Chem 2006;81:3494-504

[33] Heino J, Huhtala M, Käpylä J, Johnson MS. Evolution of collagenbased adhesion systems. Int J Biochem Cell Biol 2009;41:341-8.

[34] Shoulders MD, Raines RT. Collagen structure and stability. Annu Rev Biochem 2009;78:929-58.

[35] Hubbell JA. Materials as morphogenetic guides in tissue engineering. Curr Opin Biotechnol 2003;14:551-8.

[36] Pabbruwe MB, Kafienah W, Tarlton JF, Mistry S, Fox DJ, Hollander AP. Repair next term of meniscal previous termcartilagenext term white zone tears using a stem cell/previous termcollagennext termscaffold implant. Biomaterials 2010;31:2583-91.

[37] Park IS, Kim SH, Kim YH, Kim IH, Kim SH. A collagen/smooth muscle cell-incorporated elastic scaffold for tissue-engineered vascular grafts. J Biomater Sci Polym Ed 2009;20:1645-60.

[38] Helary C, Bataille I, Abed A, Illoul C, Anglo A, Louedec L, Letourneur D, Meddahi-Pellé A, Giraud-Guille MM. Concentrated collagen hydrogels as dermal substitutes. Biomaterials 2010;31:481-90.

[39] Wehrhan F, Nkenke E, Melnychenko I, Amann K, Schlegel KA, Goerlach C, Zimmermann WH, Schultze-Mosgau S. Skin repair using a porcine collagen I/III membrane - vascularization and epithelization properties. Dermatol Surg 2010;36:919-30.

[40] Lyons FG, Al-Munajjed AA, Kieran SM, Toner ME, Murphy CM, Duffy GP, O'Brien FJ. The healing of bony defects by cell-free collagenbased scaffolds compared to stem cell-seeded tissue engineered constructs. Biomaterials 2010;31:9232-43.

[41] Kleinmann G, Larson S, Hunter B, Stevens S, Mamalis N, Olson RJ. Collagen shields as a drug delivery system for the fourth-generation fluoroquinolones. Ophthalmologica 2007;221:51-6.

[42] Maeda M, Kadota K, Kajihara M, Suno A, Fujioka K. Sustained release of human growth hormone (hGH) from collagen film and evaluation of effect on wound healing in $\mathrm{db} / \mathrm{db}$ mice. J Control Release 2001;77:261-72.

[43] Chan BP, Hui TY, Wong MY, Yip KHK, Chan GCF. Mesenchymal stem cell-encapsulated collagen microspheres for bone tissue engineering. Tissue Eng Part C 2010;16:225-35.

[44] Chan OCM, So K-F, Chan BP. Fabrication of nano-fibrous collagen microspheres for protein delivery and effects of photochemical crosslinking on release kinetics. J Control Release 2008;129:135-43.

[45] Kawazoe N, Inoue C, Tateishi T, Chen G. A cell leakproof PLGAcollagen hybrid scaffold for cartilage tissue engineering. Biotechnol Prog 2010;26:819-26.

[46] Tierney CM, Haugh MG, Liedl J, Mulcahy F, Hayes B, O’Brien FJ. The effects of collagen concentration and crosslink density on the biological, structural and mechanical properties of collagen-GAG scaffolds for bone tissue engineering. J Mech Behav Biomed Mater 2009;2:202-9.

[47] Faralli JA, Schwinn MK, Gonzalez JM, Filla MS, Peters DM. Functional properties of fibronectin in the trabecular meshwork. Exp Eye Res 2009;88:689-93.

[48] Mao Y, Schwarzbauer JE. Fibronectin fibrillogenesis, a cellmediated matrix assembly process. Matrix Biol 2005;24:389-99.

[49] Pankov R, Yamada KM. Fibronectin at a glance. J Cell Sci 2002;115:3861-3.

[50] Rexeisen EL, Fan W, Pangburn TO, Taribagil RR, Bates FS, Lodge TP, Tsapatsis M, Kokkoli E. Self-assembly of fibronectin mimetic peptide-amphiphile nanofibers. Langmuir 2009;26:1953-9.

[51] Amaral IF, Unger RE, Fuchs S, Mendonça AM, Sousa SR, Barbosa MA, Pêgo AP, Kirkpatrick CJ. Fibronectin-mediated endothelialisation of chitosan porous matrices. Biomaterials 2009;30:5465-75.

[52] Custódio CA, Alves CM, Reis RL, Mano JF. Immobilization of fibronectin in chitosan substrates improves cell adhesion and proliferation. J Tissue Eng Regen Med 2010;4:316-23.

[53] Bush KA, Pins GD. Carbodiimide conjugation of fibronectin on collagen basal lamina analogs enhances cellular binding domains and epithelialization. Tissue Eng Part A 2010;16:829-38.

[54] Barbucci R, Magnani A, Chiumiento A, Pasqui D, Cangioli I, Lamponi S. Fibroblast cell behavior on bound and adsorbed fibronectin onto hyaluronan and sulfated hyaluronan substrates. Biomacromolecules 2005;6:638-45.

[55] Wittmer CR, Phelps JA, Saltzman WM, Tassel PRV. Fibronectin terminated multilayer films: protein adsorption and cell attachment studies. Biomaterials 2007;28:851-60.

[56] Almine JF, Bax DV, Mithieux SM, Nivison-Smith L, Rnjak J, Waterhouse A, Wise SG, Weiss AS. Elastin-based materials. Chem Soc Rev 2010;39:3371-9.

[57] Debelle L, Tamburro AM. Elastin: molecular description and, function. Int J Biochem Cell Biol 1999;31:261-72. 
[58] Muiznieks LD, Weiss AS, Keeley FW. Structural disorder and dynamics of elastin. Biochem Cell Biol 2010;88:239-50.

[59] Rodgers UR, Weiss AS. Integrin $\alpha v \beta 3$ binds a unique nonRGD site near the C-terminus of human tropoelastin. Biochimie 2004:86:173-8.

[60] Sionkowska A, Skopinska-Wisniewska J, Gawron M, Kozlowska J, Planecka A. Chemical and thermal cross-linking of collagen and elastin hydrolysates. Int J Biol Macromol 2010;47:570-7.

[61] McClure MJ, Sell SA, Simpson DG, Walpoth BH, Bowlin GL. A threelayered electrospun matrix to mimic native arterial architecture using polycaprolactone, elastin, and collagen: a preliminary study. Acta Biomater 2010;6:2422-33.

[62] Hu X, Wang X, Rnjak J, Weiss AS, Kaplan DL. Biomaterials derived from silk-tropoelastin protein systems. Biomaterials 2010;31:8121-31.

[63] Wise SG, Byrom MJ, Waterhouse A, Bannon PG, Ng MK, Weiss AS. A multilayered synthetic human elastin/polycaprolactone hybrid vascular graft with tailored mechanical properties. Acta Biomater 2010;7:295-303.

[64] Dinerman AA, Cappello J, El-Sayed M, Hoag SW, Ghandehari H. Influence of solute charge and hydrophobicity on partitioning and diffusion in a genetically engineered silk-elastin-like protein polymer hydrogel. Macromol Biosci 2010;10:1235-47.

[65] Rocha LB, Adam RL, Leite NJ, Metze K, Rossi MA. Biomineralization of polyanionic collagen-elastin matrices during cavarial bone repair. J Biomed Mater Res A 2006;79:237-45.

[66] Bessa PC, Machado R, Nürnberger S, Dopler D, Banerjee A, Cunha AM, Rodríguez-Cabello JC, Redl H, Griensven Mv, Reis RL, Casal M. Thermoresponsive self-assembled elastin-based nanoparticles for delivery of BMPs. J Control Release 2010;142:312-8.

[67] Kim W, Chaikof EL. Recombinant elastin-mimetic biomaterials: emerging applications in medicine. Adv Drug Deliv Rev 2010;62:1468-78.

[68] Martín Laura, Alonso Matilde, Girotti Alessandra, Javier Arias F, Carlos Rodríguez-Cabello J. Synthesis and characterization of macroporous thermosensitive hydrogels from recombinant elastin-like polymers. Biomacromolecules 2009;10:3015-22.

[69] Maskarinec SA, Tirrell DA. Protein engineering approaches to biomaterials design. Curr Opin Biotechnol 2005;16:422-6.

[70] Smith GF. Fibrinogen-fibrin conversion. The mechanism of fibrin-polymer formation in solution. Biochem J 1980;185:1-11.

[71] Blomäck B, Hessel B, Hogg D. Disulfide bridges in NH2-terminal part of human fibrinogen. Thromb Res 1976;8:639-58.

[72] Mosesson MW, Siebenlist KR, Meh DA. The structure and biological features of fibrinogen and fibrin. Ann N Y Acad Sci 2001:936:11-30.

[73] Siebenlist KR, Diorio JP, Budzynski AZ, Mosesson MW. The polymerization and thrombin-binding properties of des-(Bß1-42) fibrin. J Biol Chem 1990;265:18650-5.

[74] Ferry JD, Morrison PR. Preparation and properties of serum and plasma proteins. VIII. The conversion of human fibrinogen to fibrin under various conditions. J Am Chem Soc 1947;69:388-400.

[75] Lorand L, Graham RM. Transglutaminases: crosslinking enzymes with pleiotropic functions. Nat Rev Mol Cell Biol 2003:4:140-56.

[76] Spotnitz WD. Fibrin sealant: past, present, and future: a brief review. World J Surg 2010;34:632-4.

[77] Ahmann KA, Weinbaum JS, Johnson SL, Tranquillo RT. Fibrin degradation enhances vascular smooth muscle cell proliferation and matrix deposition in fibrin-based tissue constructs fabricated in vitro. Tissue Eng Part A 2010;16:3261-70.

[78] Lee Y-B, Polio S, Lee W, Dai G, Menon L, Carroll RS, Yoo S-S. Bioprinting of collagen and VEGF-releasing fibrin gel scaffolds for neural stem cell culture. Exp Neurol 2010;223:645-52.

[79] Kang S-W, Kim I-S, Park K-S, Cha B-H, Shim J-H, Kim JY, Cho DW, Rhie J-W, Lee S-H. Surface modification with fibrin/hyaluronic acid hydrogel on solid-free form-based scaffolds followed by BMP-2 loading to enhance bone regeneration. Bone 2010;48: 298-306.

[80] Durbeej M. Laminins. Cell Tissue Res 2010;339:259-68.

[81] Kikkawa Y, Takahashi N, Matsuda Y, Miwa T, Akizuki T, Kataoka A, Nomizu M. The influence of synthetic peptides derived from the laminin $\alpha 1$ chain on hepatocyte adhesion and gene expression. Biomaterials 2009:30:6888-95.

[82] Hozumi K, Akizuki T, Yamada Y, Hara T, Urushibata S, Katagiri F, Kikkawa Y, Nomizu M. Cell adhesive peptide screening of the mouse laminin $\alpha 1$ chain $\mathrm{G}$ domain. Arch Biochem Biophys 2010;503:213-22.

[83] Sarfati G, Dvir T, Elkabets M, Apte RN, Cohen S. Targeting of polymeric nanoparticles to lung metastases by surface-attachment of YIGSR peptide from laminin. Biomaterials 2010;32:152-61.
[84] Schvartz I, Seger D, Shaltiel S. Vitronectin. Int J Biochem Cell Biol 1999:31:539-44.

[85] Schleicher I, Parker A, Leavesley D, Crawford R, Upton Z, Xiao Y. Surface modification by complexes of vitronectin and growth factors for serum-free culture of human osteoblasts. Tissue Eng 2005;11:1688-98.

[86] Steele JG, Johnson G, Underwood PA. Role of serum vitronectin and fibronectin in adhesion of fibroblasts following seeding onto tissue culture polystyrene. J Biomed Mater Res A 1992;26:861-84.

[87] Reichl S. Films based on human hair keratin as substrates for cell culture and tissue engineering. Biomaterials 2009;30:6854-66.

[88] Hill P, Brantley H, Dyke MV. Some properties of keratin biomaterials: kerateines. Biomaterials 2010;31:585-93.

[89] Yamauchi K, Maniwa M, Mori T. Cultivation of fibroblast cells on keratin-coated substrata. J Biomater Sci Polym Ed 1998;9:259-70.

[90] Tachibana A, Kaneko S, Tanabe T, Yamauchi K. Rapid fabrication of keratin-hydroxyapatite hybrid sponges toward osteoblast cultivation and differentiation. Biomaterials 2005;26:297-302.

[91] Fujii T, Murai S, Ohkawa K, Hirai T. Effects of human hair and nail proteins and their films on rat mast cells. J Mater Sci: Mater Med 2008;19:2335-42.

[92] Sutherland TD, Young JH, Weisman S, Hayashi CY, Merritt DJ. Insect silk: one name, many materials. Annu Rev Entomol 2010;55:171-88.

[93] Omenetto FG, Kaplan DL. New opportunities for an ancient material. Science 2010;329:528-31.

[94] Sehnal F, Žurovec M. Construction of silk fiber core in Lepidoptera. Biomacromolecules 2004;5:666-74.

[95] Mahoney DV, Vezie DL, Eby RK, Adams WW, Kaplan D. Aspects of the morphology of dragline silk of Nephila clavipes. In: Kaplan D, Adams WW, Farmer B, Viney C, editors. Silk polymers. ACS symposium series, vol. 544. Washington, DC: American Chemical Society; 1997. p. $196-210$

[96] Sponner A, Vater W, Monajembashi S, Unger E, Grosse F, Weisshart K. Composition and hierarchical organisation of a spider silk. PLoS ONE 2007;2, e998/1-8.

[97] Beek JDv, Hess S, Vollrath F, Meier BH. The molecular structure of spider dragline silk: folding and orientation of the protein backbone. Proc Natl Acad Sci USA 2002;99:10266-71.

[98] Hardy JG, Scheibel TR. Silk-inspired polymers and proteins. Biochem Soc Trans 2009;37:677-81.

[99] Gil ES, Mandal BB, Park S-H, Marchant JK, Omenetto FG, Kaplan DL. Helicoidal multi-lamellar features of RGD-functionalized silk biomaterials for corneal tissue engineering. Biomaterials 2010;31:8953-63.

[100] Lawrence BD, Marchant JK, Pindrus MA, Omenetto FG, Kaplan DL. Silk film biomaterials for cornea tissue engineering. Biomaterials 2009;30:1299-308.

[101] Chao P-HG, Yodmuang S, Wang X, Sun L, Kaplan DL, VunjakNovakovic G. Silk hydrogel for cartilage tissue engineering. J Biomed Mater Res B 2010;95:84-90.

[102] Wang Y, Bella E, Lee CSD, Migliaresi C, Pelcastre L, Schwartz Z, Boyan $\mathrm{BD}$, Motta A. The synergistic effects of 3-D porous silk fibroin matrix scaffold properties and hydrodynamic environment in cartilage tissue regeneration. Biomaterials 2010;31:4672-81.

[103] Soffer L, Wang X, Zhang X, Kluge J, Dorfmann L, Kaplan DL, Leisk G. Silk-based electrospun tubular scaffolds for tissue-engineered vascular grafts. J Biomater Sci Polym Ed 2008;19:653-64.

[104] Zhou J, Cao C, Xilan Ma JL. Electrospinning of silk fibroin and collagen for vascular tissue engineering. Int J Biol Macromol 2010;47:514-9.

[105] Kim HJ, Kim U-J, Kim HS, Li C, Wada M, Leisk GG, Kaplan DL. Bone tissue engineering with premineralized silk scaffolds. Bone 2008:42:1226-34.

[106] Sofia S, McCarthy MB, Gronowicz G, Kaplan DL. Functionalized silk-based biomaterials for bone formation. J Biomed Mater Res 2001:54:139-48.

[107] Lammel AS, Hu X, Park S-H, Kaplan DL, Scheibel TR. Controlling silk fibroin particle features for drug delivery. Biomaterials 2010;31:4583-91.

[108] Uebersax L, Merkle HP, Meinel L. Insulin-like growth factor I releasing silk fibroin scaffolds induce chondrogenic differentiation of human mesenchymal stem cells. J Control Release 2008;127: $12-21$.

[109] Spiess K, Lammel A, Scheibel T. Recombinant spider silk proteins for applications in biomaterial. Macromol Biosci 2010;10: 998-1007.

[110] Kluge JA, Rabotyagova O, Leisk GG, Kaplan DL. Spider silks and their applications. Trends Biotechnol 2008;26:244-51. 
[111] Widhe M, Bysell H, Nystedt S, Schenning I, Malmsten M, Johansson J, Rising A, Hedhammar M. Recombinant spider silk as matrices for cell culture. Biomaterials 2010;31:9575-85.

[112] Allmeling C, Jokuszies A, Reimers K, Kall S, Vogt PM. Use of spider silk fibres as an innovative material in a biocompatible artificial nerve conduit. J Cell Mol Med 2006;10:770-7.

[113] Allmeling C, Jokuszies A, Reimers K, Kall S, Choi CY, Brandes G, Kasper C, Scheper T, Guggenheim M, Vogt PM. Spider silk fibres in artificial nerve constructs promote peripheral nerve regeneration. Cell Prolif 2008;41:408-20.

[114] Baoyong L, Jian Z, Denglong C, Min L. Evaluation of a new type of wound dressing made from recombinant spider silk protein using rat models. Burns 2010;36:891-6.

[115] Waite JH. The DOPA ephemera: a recurrent motif in invertebrates. Biol Bull 1992;183:178-84

[116] Deming TJ. Mussel byssus and biomolecular materials. Curr Opin Chem Biol 1999;3:100-5.

[117] Hwang DS, Sim SB, Cha HJ. Cell adhesion biomaterial based on mussel adhesive protein fused with RGD peptide. Biomaterials 2007;28:4039-46.

[118] Lim S, Choi YS, Kang DG, Song YH, Cha HJ. The adhesive properties of coacervated recombinant hybrid mussel adhesive proteins. Biomaterials 2010;31:3715-22.

[119] Murphy JL, Vollenweider L, Xu F, Lee BP. Adhesive performance of biomimetic adhesive-coated biologic scaffolds. Biomacromolecules 2010;11:2976-84.

[120] Beutner R, Michael J, Schwenzer B, Scharnweber D. Biological nanofunctionalization of titanium-based biomaterial surfaces: a flexible toolbox. J R Soc Interface 2010;7:S93-105.

[121] Bačáková L, Filová E, Rypáček F, Švorčík V, Starý V. Cell adhesion on artificial materials for tissue engineering. Physiol Res 2004;53:S35-45.

[122] Friess W, Uludag H, Foskett S, Biron R, Sargeant C. Characterization of absorbable collagen sponges as recombinant human bone morphogenetic protein-2 carriers. Int J Pharm 1999;185:51-60.

[123] Karageorgiou V, Tomkins M, Fajardo R, Meinel L, Snyder B, Wade K, Chen J, Vunjak-Novakovic G, Kaplan DL. Porous silk fibroin 3-D scaffolds for delivery of bone morphogenetic protein-2 in vitro and in vivo. J Biomed Mater Res A 2006;78:324-34.

[124] Wongpanit P, Ueda H, Tabata Y, Rujiravanit R. In vitro and in vivo release of basic fibroblast growth factor using a silk fibroin scaffold as delivery carrier. J Biomater Sci Polym Ed 2010;21:1403-19.

[125] Kleinheinz J, Jung S, Wermker K, Fischer C, Joos U. Release kinetics of VEGF165 from a collagen matrix and structural matrix changes in a circulation model. Head Face Med 2010;6:1-7.

[126] Kilian O, Hossain H, Flesch I, Sommer U, Nolting H, Chakraborty T, Schnettler R. Elution kinetics, antimicrobial efficacy, and degradation and microvasculature of a new gentamicin-loaded collagen fleece. J Biomed Mater Res B 2008;90:210-22.

[127] Wang X, Zhang X, Castellot J, Herman I, Iafrati M, Kaplan DL Controlled release from multilayer silk biomaterial coatings to modulate vascular cell responses. Biomaterials 2008;29:894-903.

[128] Zhao J, Shinkai M, Takezawa T, Ohba S, Chung U-I, Nagamune T. Bone regeneration using collagen type I vitrigel with bone morphogenetic protein-2. J Biosci Bioeng 2009;107:318-23.

[129] Han D, Liu W, Ao Q, Wang G. Optimal delivery systems for bone morphogenetic proteins in orthopedic applications should model initial tissue repair structures by using a heparin-incorporated fibrin-fibronectin matrix. Med Hypotheses 2008;71:374-8.

[130] Shields LB, Raque GH, Glassman SD, Campbell M, Vitaz T, Harpring J Shields CB. Adverse effects associated with high-dose recombinant human bone morphogenetic protein-2 use in anterior cervical spine fusion. Spine 2006;31:542-7.

[131] Hersel U, Dahmen C, Kessler H. RGD modified polymers: biomaterials for stimulated cell adhesion and beyond. Biomaterials 2003;24:4385-415.

[132] Murphy AR, Kaplan DL. Biomedical applications of chemicallymodified silk fibroin. J Mater Chem 2009;19:6443-50.

[133] Rafat M, Li F, Fagerholm P, Lagali NS, Watsky MA, Munger R, Matsuura T, Griffith M. PEG-stabilized carbodiimide crosslinked collagen-chitosan hydrogels for corneal tissue engineering. Biomaterials 2008;29:3960-72.

[134] Zhang Y-Q, Ma Y, Xia Y-Y, Shen W-D, Mao J-P, Zha X-M, Shirai K, Kiguchi K. Synthesis of silk fibroin-insulin bioconjugates and their characterization and activities in vivo. J Biomed Mater Res B 2006;79:275-83.

[135] Chatterjee S, Barbora L, Cameotra SS, Mahanta P, Goswami P. Silk-fiber immobilized lipase-catalyzed hydrolysis of emulsified sunflower oil. Appl Biochem Biotechnol 2009;157:593-600.
[136] Yeo S, Oh J-E, Jeong L, Lee TS, Lee SJ, Park WH, Min B-M. Collagen-based biomimetic nanofibrous scaffolds: preparation and characterization of collagen/silk fibroin bicomponent nanofibrous structures. Biomacromolecules 2008;9:1106-16.

[137] Kimura Y, Tsuji W, Yamashiro H, Toi M, Inamoto T, Tabata Y. In situ adipogenesis in fat tissue augmented by collagen scaffold with gelatin microspheres containing basic fibroblast growth factor. J Tissue Eng Regen Med 2010;4:55-61.

[138] Adhirajan N, Shanmugasundaram N, Shanmuganathan S, Babu M. Functionally modified gelatin microspheres impregnated collagen scaffold as novel wound dressing to attenuate the proteases and bacterial growth. Eur J Pharm Sci 2009;36:235-45.

[139] Wang X, Wenk E, Matsumoto A, Meinel L, Li C, Kaplan DL. Silk microspheres for encapsulation and controlled release. J Control Release 2007;117:360-70.

[140] Wu F, Jin T. Polymer-based sustained-release dosage forms for protein drugs, challenges, and recent advances. AAPS PharmSciTech 2009;9:1218-29.

[141] Langer R, Tirrell DA. Designing materials for biology and medicine. Nature 2004;428:487-92

[142] Sato AK, Viswanathan M, Kent RB, Wood CR. Therapeutic peptides: technological advances driving peptides into development. Curr Opin Biotechnol 2006; 17:638-42.

[143] Kastin AJ. Handbook of biologically active peptides. Burlington: Elsevier; 2006.

[144] Kyle S, Aggeli A, Ingham E, McPherson MJ. Production of selfassembling biomaterials for tissue engineering. Trends Biotechnol 2009;27:423-33.

[145] Báez J, Olsen D, Polarek JW. Recombinant microbial systems for the production of human collagen and gelatin. Appl Microbiol Biotechnol 2005;69:245-52.

[146] Olsen D, Yang C, Bodo M, Chang R, Leigh S, Baez J, Carmichael D, Perälä M, Eija-Riitt, Hämäläinen, Jarvinen M, Polarek J. Recombinant collagen and gelatin for drug delivery. Adv Drug Deliv Rev 2003:55:1547-67.

[147] Myllyharju J, Nokelainen M, Vuorela A, Kivirikko KI. Expression of recombinant human type I-III collagens in the yeast Pichia pastoris. Biochem Soc Trans 2000;28:353-7.

[148] Pulkkinen HJ, Tiitu V, Valonen P, Jurvelin JS, Lammi MJ, Kiviranta I. Engineering of cartilage in recombinant human type II collagen gel in nude mouse model in vivo. Osteoarthritis Cartilage 2010;18:1077-87.

[149] Dame MK, Varani J. Recombinant collagen for animal product-free dextran microcarriers. In Vitro Cell Dev Biol Anim 2008;44:407-14

[150] Liu W, Merrett K, Griffith M, Fagerholm P, Dravida S, Heyne B, Scaiano JC, Watsky MA, Shinozaki N, Lagali N, Munger R, Li F. Recombinant human collagen for tissue engineered corneal substitutes. Biomaterials 2008;29:1147-58.

[151] Wang Y, Cui FZ, Hu K, Zhu XD, Fan DD. Bone regeneration by using scaffold based on mineralized recombinant collagen. J Biomed Mater Res B 2008;86:29-35.

[152] Ito H, Steplewski A, Alabyeva T, Fertala A. Testing the utility of rationally engineered recombinant collagen-like proteins for applications in tissue engineering. J Biomed Mater Res A 2006;76A:551-60.

[153] Vendrely C, Scheibel T. Biotechnological production of spider-silk proteins enables new applications. Macromol Biosci 2007;7:401-9.

[154] Scheibel T. Spider silks: recombinant synthesis, assembly, spinning, and engineering of synthetic proteins. Microb Cell Fact 2004;3:1-10

[155] Prince JT, McGrath KP, DiGirolamo CM, Kaplan DL. Construction, cloning, and expression of synthetic genes encoding spider dragline silk. Biochemistry 1995;34:10879-85.

[156] Zhou Y, Wu S, Conticello VP. Genetically directed synthesis and spectroscopic analysis of a protein polymer derived from a flag elliform silk sequence. Biomacromolecules 2001;2:111-25.

[157] Huemmerich D, Helsen CW, Quedzuweit S, Oschmann J, Rudolph $\mathrm{R}$, Scheibel T. Primary structure elements of spider dragline silks and their contribution to protein solubility. Biochemistry 2004;43:13604-12.

[158] Fahnestock SR, Bedzyk LA. Production of synthetic spider dragline silk protein in Pichia pastoris. Appl Microbiol Biotechnol 1997;47:33-9.

[159] McPherson DT, Xu J, Urry DW. Product purification by reversible phase transition following Escherichia coli expression of genes encoding up to 251 repeats of the elastomeric pentapeptide GVGVP. Protein Expr Purif 1996;7:51-77.

[160] Urry DW. Thermally driven self-assembly, molecular structuring and entropic mechanisms in elastomeric polypeptides. In: Balaram 
P, Ramaseshan S, editors. Molecular conformation and biological interactions. Bangalore, India: Indian Acad. Sci.; 1991. p. 555-83.

[161] Urry DW. Free energy transduction in polypeptides and proteins based on inverse temperature transitions. Prog Biophys Mol Biol 1992:57:23-57.

[162] Hassouneh W, Christensen T, Chilkoti A. Elastin-like polypeptides as a purification tag for recombinant proteins. In: Coligan JE, Dunn BM, Speicher DW, Wingfield PT, editors. Current protocols in protein science. New Jersey: John Wiley \& Sons Inc.; 2010. p. 1-16.

[163] Meyer DE, Chilkoti A. Purification of recombinant proteins by fusion with thermally-responsive polypeptides. Nature 1999;17: 1112-5.

[164] Wu W-Y, Fong BA, Gilles AG, Wood DW. Recombinant protein purification by self-cleaving elastin-like polypeptide fusion tag. In: Coligan JE, Dunn BM, Speicher DW, Wingfield PT, editors. Current protocols in protein science. New Jersey: John Wiley \& Sons Inc.; 2009. p. $1-18$

[165] Urry DW, Luan CH, Parker TM, Gowda DC, Prasad KU, Reid MC, Safavy A. Temperature of polypeptide inverse temperature transition depends on mean residue hydrophobicity. J Am Chem Soc 1991;113:4346-8.

[166] Luan CH, Urry DW. Elastic, plastic, and hydrogel protein-based polymers. In: Mark JE, editor. Polymer data handbook. New York: Oxford University Press; 1999. p. 78-89.

[167] Wu X, Sallach R, Haller CA, Caves JA, Nagapudi K, Conticello VP, Levenston ME, Chaikof EL. Alterations in physical cross-linking modulate mechanical properties of two-phase protein polymer networks. Biomacromolecules 2005;6:3037-44.

[168] Barbosa JS, Ribeiro A, Testera AM, Alonso M, Arias FJ, RodríguezCabello JC, Mano JF. Development of biomimetic chitosanbased hydrogels using an elastin-like polymer. Adv Eng Mater 2010;12:B37-44.

[169] Costa RR, Custódio CA, Testera AM, Arias FJ, Rodríguez-Cabello JC, Alves NM, Mano JF. Stimuli-responsive thin coatings using elastin-like polymers for biomedical applications. Adv Funct Mater 2009;19:3210-8.

[170] Nicol A, Gowda DC, Parker TM, Urry DW. Cell adhesive properties of bioelastic materials containing cell attachment sequences. In: Gebelein C, Carraher C, editors. Biotechnology and bioactive polymers. New York: Plenum Press; 1994. p. 95-114.

[171] Urry DW, Nicol A, Gowda DC, Hoban LD, McKee A, Williams T, Olsen DB, Cox BA. Medical applications of bioelastic materials. In: Gebelein CG, editor. Biotechnological polymers: medical, pharmaceutical and industrial applications. Atlanta, Georgia: Technomic Publishing Co. Inc.; 1993. p. 82-103.

[172] Numata K, Hamasaki J, Subramanian B, Kaplan DL. Gene delivery mediated by recombinant silk proteins containing cationic and cell binding motifs. J Control Release 2010;146:136-43.

[173] Arias FJ, Reboto V, Martín S, López I, Rodríguez-Cabello JC. Tailored recombinant elastin-like polymers for advanced biomedical and nano(bio)technological applications. Biotechnol Lett 2006;28:687-95.

[174] Benesch J, Mano JF, Reis RL. Proteins and their peptide motifs in acellular apatite mineralization of scaffolds for tissue engineering. Tissue Eng Part B 2008;14:433-45.

[175] Ganss B, Kim RH, Sodek J. Bone sialoprotein. Crit Rev Oral Biol Med 1999;10:79-98.

[176] Gomes S, Leonor IB, Mano JF, Reis RL, Kaplan DL. Spider silk-bone sialoprotein as a novel fusion protein for bone tissue engineering. Soft Matter 2011;7:4964-73.

[177] Huang J, Wong C, George A, Kaplan DL. The effect of genetically engineered spider silk-dentin matrix protein 1 chimeric protein on hydroxyapatite nucleation. Biomaterials 2007;28:2358-67.

[178] Gomes S, Leonor IB, Mano JF, Reis RL, Kaplan DL. Antimicrobial functionalized genetically engineered spider silk. Biomaterials 2011;32:4255-66.

[179] Jang J-H, Chung C-P. Engineering and expression of a recombinant fusion protein possessing fibroblast growth factor-2 and fibronectin fragment. Biotechnol Lett 2004;26:1837-40.

[180] Kawase Y, Ohdate Y, Shimojo T, Taguchi Y, Kimizuka F, Kato I. Construction and characterization of a fusion protein with epidermal growth factor and the cell-binding domain of fibronectin. FEBS Lett 1992;298:126-8

[181] Hayashi M, Tomita M, Yoshizato K. Production of EGF-collagen chimeric protein which shows the mitogenic activity. Biochim Biophys Acta 2001;1528:187-95.

[182] Nettles DL, Chilkoti A, Setton LA. Applications of elastinlike polypeptides in tissue engineering. Adv Drug Deliv Rev 2010;62:1479-85.
[183] Vrhovski B, Weiss AS. Biochemistry of tropoelastin. Eur J Biochem 1998;258:1-18.

[184] Janmey PA, Winer JP, Weisel JW. Fibrin gels and their clinical and bioengineering applications. J R Soc Interface 2009;6:1-10.

[185] Lane EB, McLean WHI. Keratins and skin disorders. J Pathol 2004;204:355-66.

[186] Miyagi Y, Chiu LLY, Cimini M, Weisel RD, Radisic M, Li RK. Biodegradable collagen patch with covalently immobilized VEGF for myocardial repair. Biomaterials 2011;32:1280-90.

[187] Shen YH, Shoichet MS, Radisi M. Vascular endothelial growth factor immobilized in collagen scaffold promotes penetration and proliferation of endothelial cells. Acta Biomater 2008;4:477-89.

[188] Nillesen STM, Geutjes PJ, Wismans R, Schalkwijk J, Daamen WF, Kuppevelt THv. Increased angiogenesis and blood vessel maturation in acellular collagen-heparin scaffolds containing both FGF2 and VEGF. Biomaterials 2007;28:1123-31.

[189] Sun B, Chen B, Zhao Y, Sun W, Chen K, Zhang J, Wei Z, Xiao Z, Dai J. Crosslinking heparin to collagen scaffolds for the delivery of human platelet-derived growth factor. J Biomed Mater Res B 2009;91:366-72.

[190] Teixeira S, Yang L, Dijkstra PJ, Ferraz MP, Monteiro FJ. Heparinized hydroxyapatite/collagen three-dimensional scaffolds for tissue engineering. J Mater Sci Mater Med 2010;21:2385-92.

[191] Wu JM, Xu YY, Li ZH, Yuan XY, Wang PF, Zhang XZ, Liu YQ, Guan J, Guo Y, Li RX, Zhang H. Heparin-functionalized collagen matrices with controlled release of basic fibroblast growth factor. J Mater Sci Mater Med 2011;22:107-14.

[192] Zhao Y, Zhang J, Wang X, Chen B, Xiao Z, Shi C, Wei Z, Hou X, Wang $\mathrm{Q}$. Dai J. The osteogenic effect of bone morphogenetic protein-2 on the collagen scaffold conjugated with antibodies. J Control Release 2010;141:30-7.

[193] He Q, Zhao Y, Chen B, Xiao Z, Zhang J, Chen L, Chen W, Deng F, Dai J. Improved cellularization and angiogenesis using collagen scaffolds chemically conjugated with vascular endothelial growth factor. Acta Biomater 2010;7:1084-93.

[194] Takeda Y, Tsujigiwa H, Nagatsuka H, Nagai N, Yoshinobu J, Okano M, Fukushima K, Takeuchi A, Yoshino T, Nishizaki K. Regeneration of rat auditory ossicles using recombinant human BMP-2/collagen composites. J Biomed Mater Res A 2005;73A:133-41.

[195] Côté M-F, Laroche G, Gagnon E, Chevallier P, Doillon CJ. Denatured collagen as support for a FGF-2 delivery system: physicochemical characterizations and in vitro release kinetics and bioactivity. Biomaterials 2004;25:3761-72.

[196] Maehara H, Sotome S, Yoshii T, Torigoe I, Kawasaki Y, Sugata Y, Yuasa M, Hirano M, Mochizuki N, Kikuchi M, Shinomiya K, Okawa A. Repair of large osteochondral defects in rabbits using porous hydroxyapatite/collagen ( $\mathrm{HAp} / \mathrm{Col}$ ) and fibroblast growth factor-2 (FGF-2). J Orthop Res 2010;28:677-86.

[197] Gavénis K, Klee D, Pereira-Paz RM, Walter Mv, Mollenhauer J, Schneider U, Schmidt-Rohlfing B. BMP-7 loaded microspheres as a new delivery system for the cultivation of human chondrocytes in a collagen type-I gel. J Biomed Mater Res B 2007;82: 275-83.

[198] Borselli C, Ungaro F, Oliviero O, d'Angelo I, Quaglia F, Rotonda MIL, Netti PA. Bioactivation of collagen matrices through sustained VEGF release from PLGA microspheres. J Biomed Mater Res A 2010;92:94-102

[199] Chou C-H, Cheng WTK, Lin C-C, Chang C-H, Tsai C-C, Lin F-H. TGF-beta1 immobilized tri-co-polymer for articular cartilage tissue engineering. J Biomed Mater Res B 2006;77:338-48.

[200] Srouji S, Rachmiel A, Blumenfeld I, Livne E. Mandibular defect repair by TGF-beta and IGF-1 released from a biodegradable osteoconductive hydrogel. J Craniomaxillofac Surg 2005;33:79-84

[201] Kuo Y-C, Ku I-N. Effects of gel concentration, human fibronectin, and cation supplement on the tissue-engineered cartilage. Biotechnol Prog 2007;23:238-45.

[202] Fan H, Hu Y, Li X, Wu H, Lv R, Bai J, Wang J, Qin L. Ectopic cartilage formation induced by mesenchymal stem cells on porous gelatin-chondroitin-hyaluronate scaffold containing microspheres loaded with TGF-beta1. Int J Artif Organs 2006;29:602-11

[203] Ogawa T, Akazawa T, Tabata Y. In vitro proliferation and chondrogenic differentiation of rat bone marrow stem cells cultured with gelatin hydrogel microspheres for TGF-beta1 release. J Biomater Sci Polym Ed 2010;21:609-21.

[204] Kempen DHR, Lu L, Heijink A, Hefferan TE, Creemers LB, Maran A, Yaszemski MJ, Dhert WJA. Effect of local sequential VEGF and BMP-2 delivery on ectopic and orthotopic bone regeneration. Biomaterials 2009;30:2816-25 
[205] Kempen DHR, Lu L, Hefferan TE, Creemers LB, Maran A, Classic KL, Dhert WJA, Yaszemski MJ. Retention of in vitro and in vivo BMP-2 bioactivities in sustained delivery vehicles for bone tissue engineering. Biomaterials 2008;29:3245-52.

[206] Royce SM, Askari M, Marra KG. Incorporation of polymer microspheres within fibrin scaffolds for the controlled delivery of FGF-1. J Biomater Sci Polym Ed 2004;15:1327-36.

[207] Chung Y-I, Ahn K-M, Jeon S-H, Lee S-Y, Lee J-H, Tae G. Enhanced bone regeneration with BMP-2 loaded functional nanoparticle-hydrogel complex. J Control Release 2007;121:91-9.

[208] Park K-H, Kim H, Moon S, Na K. Bone morphogenic protein-2 (BMP2) loaded nanoparticles mixed with human mesenchymal stem cell in fibrin hydrogel for bone tissue engineering. J Biosci Bioeng 2009;108:530-7.

[209] Campbell PG, Miller ED, Fisher GW, Walker LM, Weiss LE. Engineered spatial patterns of FGF-2 immobilized on fibrin direct cell organization. Biomaterials 2005;26:6762-70.

[210] Lee J, Choi WI, Tae G, Kim YH, Kang SS, Kim SE, Kim S-H, Jung $\mathrm{Y}, \mathrm{Kim} \mathrm{SH}$. Enhanced regeneration of the ligament-bone interface using a poly(L-lactide-co- $\varepsilon$-caprolactone) scaffold with local delivery of cells/BMP-2 using a heparin-based hydrogel. Acta Biomater 2011;7:244-57.

[211] Kim M, Lee JY, Jones CN, Revzin A, Tae G. Heparin-based hydrogel as a matrix for encapsulation and cultivation of primary hepatocytes. Biomaterials 2010;31:3596-603.

[212] Gotoh Y, Niimi S, Hayakawa T, Miyashita T. Preparation of lactose-silk fibroin conjugates and their application as a scaffold for hepatocyte attachment. J Mater Chem 2004;25:1131-40.

[213] Fan H, Liu H, Wang Y, Toh SL, Goh JC. Development of a silk cablereinforced gelatin/silk fibroin hybrid scaffold for ligament tissue engineering. Cell Transplant 2008;17:1389-401.

[214] Qiang Lu, Xiaohui Zhang, Xiao Hu, Kaplan DL. Green process to prepare silk fibroin/gelatin biomaterial scaffolds. Macromol Biosci 2010;10:289-98.

[215] Seo Y-K, Yoon H-H, Song K-Y, Kwon S-Y, Lee H-S, Park Y-S, Park $\mathrm{J}-\mathrm{K}$. Increase in cell migration and angiogenesis in a composite silk scaffold for tissue-engineered ligaments. J Orthop Res 2009;27:495-503.

[216] Chen X, Qia Y-Y, Wang L-L, Yin Z, Yin G-L, Zou X-H, Ouyang H-W. Ligament regeneration using a knitted silk scaffold combined with collagen matrix. Biomaterials 2008;29:3683-92.

[217] Takezawa T, Ozaki K, Takabayashi C. Reconstruction of a hard connective tissue utilizing a pressed silk sheet and type-I collagen as the scaffold for fibroblasts. Tissue Eng 2007;13:1357-66.

[218] Kirker-Head C, Karageorgiou V, Hofmann S, Fajardo R, Betz O, Merkle HP, Hilbe M, Rechenberg Bv, McCool J, Abrahamsen L, Nazarian A, Cory E, Curtis M, Kaplan DL, Meinel L. BMP-silk composite matrices heal critically sized femoral defects. Bone 2007;41:247-455.

[219] Wenk E, Meinel AJ, Wildy S, Merkle HP, Meinel L. Microporous silk fibroin scaffolds embedding PLGA microparticles for controlled growth factor delivery in tissue engineering. Biomaterials 2009;30:2571-81.

[220] Gil ES, Frankowski DJ, Bowman MK, Gozen AO, Hudson SM, Spontak RJ. Mixed protein blends composed of gelatin and Bombyx mori silk fibroin: effects of solvent-induced crystallization and composition. Biomacromolecules 2006;7:728-35.

[221] Shen W, Chen X, Chen J, Yin Z, Heng BC, Chen W, Ouyang H-W. The effect of incorporation of exogenous stromal cell-derived factor1 alpha within a knitted silk-collagen sponge scaffold on tendon regeneration. Biomaterials 2010;31:7239-49.

[222] Zhang C, Baez J, Pappu KM, Glatz CE. Purification and characterization of a transgenic corn grain-derived recombinant collagen type I alpha 1. Biotechnol Prog 2009;25:1660-8.

[223] Nokelainen M, Tu H, Vuorela A, Notbohm H, Kivirikko KI, Myllyharju J. High-level production of human type I collagen in the yeast Pichia pastoris. Yeast 2001;18:797-806.

[224] Olsen DR, Leigh SD, Chang R, McMullin H, Ong W, Tai E, Chisholm G, Birk DE, Berg RA, Hitzeman RA, Toma PD. Production of human type I collagen in yeast reveals unexpected new insights into the molecular assembly of collagen trimers. J Biol Chem 2001;276: 24038-43.

[225] Toman PD, Chisholm G, McMullin H, Giere LM, Olsen DR, Kovach RJ, Leigh SD, Fong BE, Chang R, Daniels GA, Berg RA, Hitzeman RA. Production of recombinant human type I procollagen trimers using a four-gene expression system in the yeast Saccharomyces cerevisiae. J Biol Chem 2000;275:23303-9.

[226] Fertala A, Sieron AL, Ganguly A, Li SW, Ala-Kokko L, Anumula KR, Prockop DJ. Synthesis of recombinant human procollagen
II in a stably transfected tumour cell line (HT1080). Biochem J 1994;298:31-7.

[227] Geddis AE, Prockop DJ. Expression of human COL1A1 gene in stably transfected HT1080 cells: the production of a thermostable homotrimer of type I collagen in a recombinant system. Matrix 1993;13:399-405.

[228] Myllyharju J, Lamberg A, Notbohm H, Fietzek PP, Pihlajaniem T, Kivirikko KI. Expression of wild-type and modified proo chains of human type I procollagen in insect cells leads to the formation of stable $[\alpha 1(\mathrm{I})] 2 \alpha 2$ (I) collagen heterotrimers and $[\alpha 1(\mathrm{I})] 3$ homotrimers but not $[\alpha 2(\mathrm{I})] 3$ homotrimers. J Biol Chem 1997;272:21824-30.

[229] Tomita M, Kitajima T, Yoshizato K. Formation of recombinant human procollagen I heterotrimers in a baculovirus expression system. J Biochem 1997;121:1061-9.

[230] John DCA, Watson R, Kind AJ, Scott AR, Kadler KE, Bulleid NJ. Expression of an engineered form of recombinant procollagen in mouse milk. Nat Biotechnol 1999;17:385-9.

[231] Toman PD, Pieper F, Sakai N, Karatzas C, Platenburg E, Wit Id, Samuel C, Dekker A, Daniels GA, Berg RA, Platenburg GJ. Production of recombinant human type I procollagen homotrimer in the mammary gland of transgenic mice. Transgenic Res 1999;8: 415-27.

[232] Buechter DD, Paolella DN, Leslie BS, Brown MS, Mehos KA, Gruskin EA. Co-translational Incorporation of trans-4-hydroxyproline into recombinant proteins in bacteria. J Biol Chem 2003;278: 645-50.

[233] Nokelainen M, Helaakoski T, Myllyharju J, Notbohm H, Pihlajaniemi T, Fietzek PP, Kivirikko KI. Expression and characterization of recombinant human type II collagens with low and high contents of hydroxylysine and its glycosylated forms. Matrix Biol 1998:16:329-38.

[234] Vuorela A, Myllyharju J, Nissi R, Pihlajaniemi T, Kivirikko KI. Assembly of human prolyl 4-hydroxylase and type III collagen in the yeast Pichia pastoris: formation of a stable enzyme tetramer requires coexpression with collagen and assembly of a stable collagen requires coexpression with prolyl 4-hydroxylase. EMBO 1997; $16: 6702-12$

[235] Vaughan PR, Galanis M, Richards KM, Tebb TA, Ramshaw JAM, Werkmaister JA. Production of recombinant hydroxylated human type III collagen fragment in Saccharomyces cerevisiae. DNA Cell Biol 1998; 17:511-8.

[236] Lamberg A, Helaakoski T, Myllyharju J, Peltonen S, Notbohm H, Pihlajaniemi T, Kivirikko KI. Characterization of human type III collagen expressed in a baculovirus system. Production of a protein with a stable triple helix requires coexpression with the two types of recombinant prolyl 4-hydroxylase subunit. J Biol Chem 1996;271:11988-95.

[237] Tomita M, Ohkura N, Ito M, Kato T, Royce PM, Kitajima T. Biosynthesis of recombinant human pro-alpha 1 (III) chains in a baculovirus expression system: production of disulphide-bonded and nondisulphide-bonded species containing full-length triple helices. Biochem J 1995;312:847-53.

[238] Tomita M, Munetsuna H, Sato T, Adachi T, Hino R, Hayashi M, Shimizu K, Nakamura N, Tamura T, Yoshizato K. Transgenic silkworms produce recombinant human type III procollagen in cocoons. Nat Biotechnol 2003;21:52-6.

[239] Fichard A, Tillet E, Delacoux F, Garrone R, Ruggiero F. Human recombinant $\alpha 1(\mathrm{~V})$ collagen chain. J Biol Chem 1997;272:30083-7.

[240] Tillet E, Wiedemann H, Golbik R, Pan T-C, Zhang R-Z, Mann K, Chu M-L, Timpl R. Recombinant expression and structural and binding properties of $\alpha 1(\mathrm{VI})$ and $\alpha 2(\mathrm{VI})$ chains of human collagen type VI. Eur J Biochem 1994;221:177-87.

[241] Chen M, Costa FK, Lindvay CR, Han Y-P, Woodley DT. The recombinant expression of full-length type VII collagen and characterization of molecular mechanisms underlying dystrophic epidermolysis bullosa. J Biol Chem 2002;277:2118-24.

[242] Frischholz S, Beier F, Girkontaite I, Wagner K, Pöschl E, Turnay J, Mayer U, Mark Kvd. Characterization of human type X procollagen and its NC-1 domain expressed as recombinant proteins in HEK293 cells. J Biol Chem 1998;273:4547-55.

[243] Warner LR, Blasick CM, Brown RJ, Oxford JT. Expression, purification, and refolding of recombinant collagen alpha1(XI) amino terminal domain splice variants. Protein Expr Purif 2007;52 403-9.

[244] Steplewski A, Majsterek I, McAdams E, Rucker E, Brittingham RJ, Ito $\mathrm{H}$, Hirai K, Adachi E, Jimenez SA, Fertala A. Thermostability gradient in the collagen triple helix reveals its multi-domain structure. J Mol Biol 2004;338:989-98. 
[245] Werten MWT, Teles H, Moers APHA, Wolbert EJH, Sprakel J, Eggink $\mathrm{G}$, Wolf FA. Precision gels from collagen-inspired triblock copolymers. Biomacromolecules 2009;10:1106-13.

[246] Sallach RE, Conticello VP, Chaikof EL. Expression of a recombinant elastin-like protein in Pichia pastoris. Biotechnol Prog 2009;25:1810-8.

[247] Jordan SW, Haller CA, Sallach RE, Apkarian RP, Hanson SR, Chaikof EL. The effect of a recombinant elastin-mimetic coating of an ePTFE prosthesis on acute thrombogenicity in a baboon arteriovenous shunt. Biomaterials 2007;28:1191-7.

[248] Nagapudi K, Brinkman WT, Leisen J, Thomas BS, Wright ER, Haller C, Wu X, Apkarian RP, Conticello VP, Chaikof EL. Protein-based thermoplastic elastomers. Macromolecules 2005:38:345-54.

[249] Panitch A, Yamaoka T, Fournier MJ, Mason TL, Tirrell DA. Design and biosynthesis of elastin-like artificial extracellular matrix proteins containing periodically spaced fibronectin CS5 domains. Macromolecules 1999;32:1701-3.

[250] Sallacha RE, Cui W, Balderrama F, Martinez AW, Wen J, Haller CA, Taylor JV, Wright Jr ER, Long Jr RC, Chaikof EL. Long-term biostability of self-assembling protein polymers in the absence of covalent crosslinking. Biomaterials 2010;31:779-91.

[251] Woodhouse KA, Klement P, Chen V, Gorbet MB, Keeley FW, Stahl R, Fromstein JD, Bellingham CM. Investigation of recombinant human elastin polypeptides as non-thrombogenic coatings. Biomaterials 2004;25:4543-53.

[252] Wright ER, McMillan RA, Cooper A, Apkarian RP, Conticello VP. Thermoplastic elastomer hydrogels via self-assembly of an elastinmimetic triblock polypeptide. Adv Funct Mater 2002;12:149-54.

[253] Yamaoka T, Tamura T, Seto Y, Tada T, Kunugi S, Tirrell DA. Mechanism for the phase transition of a genetically engineered elastin model peptide (VPGIG) 40 in aqueous solution. Biomacromolecules 2003:4:1680-5.

[254] Nagapudi K, Brinkman WT, Leisen JE, Huang L, McMillan RA, Apkarian RP, Conticello VP, Chaikof EL. Photomediated solid-state cross-linking of an elastin-mimetic recombinant protein polymer. Macromolecules 2002;35:1730-7.

[255] Rabotyagova O, Cebe P, Kaplan DL. Self-assembly of genetically engineered spider silk block copolymers. Biomacromolecules 2009;10:229-36.

[256] Rabotyagova OS, Cebe P, Kaplan DL. Role of polyalanine domains in $\beta$-sheet formation in spider silk block copolymers. Macromol Biosci 2010;10:49-59.

[257] Arcidiacono S, Mello C, Kaplan DL, Cheley S, Bayley H. Purification and characterization of recombinant spider silk expressed in Escherichia coli. Appl Microbiol Biotechnol 1998;49:31-8.

[258] Fahnestock SR, Irwin SL. Synthetic spider dragline silk proteins and their production in Escherichia coli. Appl Microbiol Biotechnol 1997:47:23-32.

[259] Lewis RV, Hinman M, Kothakota S, Fournier MJ. Expression and purification of a spider silk protein: a new strategy for producing repetitive proteins. Protein Expr Purif 1996;7:400-6.

[260] Fukushima Y. Genetically engineered syntheses of tandem repetitive polypeptides consisting of glycine-rich sequence of spider dragline silk. Biopolymers 1998;45:269-79.

[261] Mello CM, Soares JW, Arcidiacono S, Butle MM. Acid extraction and purification of recombinant spider silk proteins. Biomacromolecules 2004;5:1849-52

[262] Butler SP, O'Sickey TK, Lord ST, Lubon H, Gwazdauskas FC, Velande $\mathrm{WH}$. Secretion of recombinant human fibrinogen by the murine mammary gland. Transgenic Res 2004;13:437-50.

[263] Tojo N, Miyagia I, Miuraa M, Ohi H. Recombinant human fibrinogen expressed in the yeast Pichia pastoris was assembled and biologically active. Protein Expr Purif 2008;59:289-96.

[264] Cutler SM, Garca AJ. Engineering cell adhesive surfaces that direct integrin $\alpha 5 \beta 1$ binding using a recombinant fragment of fibronectin. Biomaterials 2003;24:1759-70.

[265] Rico P, González-García C, Petrie TA, García AJ, Salmerón-Sánchez M. Molecular assembly and biological activity of a recombinant fragment of fibronectin (FNIII(7-10)) on poly(ethyl acrylate). Colloids Surf B 2010:78:310-6.

[266] Brewster LP, Washington C, Brey EM, Gassman A, Subramanian A, Calceterra J, Wolf W, Hall CL, Velander WH, Burgess WH, Greisle HP. Construction and characterization of a thrombin-resistant designer FGF-based collagen binding domain angiogen. Biomaterials 2008;29:327-36.
[267] Pang Y, Wang X, Ucuzian AA, Brey EM, Burgess WH, Jones KJ, Alexander TD, Greisler HP. Local delivery of a collagen-binding FGF-1 chimera to smooth muscle cells in collagen scaffolds for vascular tissue engineering. Biomaterials 2010;31:87885.

[268] Yan X, Chen B, Lin Y, Li Y, Xiao Z, Hou X, Tan Q, Dai J. Acceleration of diabetic wound healing by collagen-binding vascular endothelial growth factor in diabetic rat model. Diabetes Res Clin Pract 2010;90:66-72

[269] Hashi H, Hatai M, Kimizuka F, Kato I, Yaoi Y. Angiogenic activity of a fusion protein of the cell-binding domain of fibronectin and basic fibroblast growth factor. Cell Struct Funct 1994;19: 37-47.

[270] Nishi N, Matsushita O, Yuube K, Miyanaka H, Okabe A, Wada F. Collagen-binding growth factors: production and characterization of functional fusion proteins having a collagen-binding domain. Proc Natl Acad Sci USA 1998;95:7018-23.

[271] Sheng Z, Chang S-B, Chirico WJ. Expression and purification of a biologically active basic fibroblast growth factor fusion protein. Protein Expr Purif 2003;27:267-71.

[272] Ogiwara K, Nagaoka M, Cho C-S, Akaike T. Construction of a novel extracellular matrix using a new genetically engineered epidermal growth factor fused to IgG-Fc. Biotechnol Lett 2005;27: $1633-7$.

[273] Qiu W, Huang Y, Teng W, Cohn CM, Cappello J, Wu X. Complete recombinant silk-elastinlike protein-based tissue scaffold. Biomacromolecules 2010;11:3219-27.

[274] Yang M, Tanaka C, Yamauchi K, Ohgo K, Kurokawa M, Asakura T. Silk-like materials constructed from sequences of Bombyx mori silk fibroin, fibronectin, and elastin. J Biomed Mater Res A 2008;84:353-63.

[275] Kambe Y, Yamamoto K, Kojima K, Tamada Y, Tomita N. Effects of RGDS sequence genetically interfused in the silk fibroin light chain protein on chondrocyte adhesion and cartilage synthesis. Biomaterials 2010;31:7503-11

[276] Du C, Wang M, Liu J, Pan M, Cai Y, Yao J. Improvement of thermostability of recombinant collagen-like protein by incorporating a foldon sequence. Appl Microbiol Biotechnol 2008;79:195-202.

[277] Chen B, Lin H, Wang J, Zhao Y, Wang B, Zhao W, Sun W, Dai J. Homogeneous osteogenesis and bone regeneration by demineralized bone matrix loading with collagen-targeting bone morphogenetic protein-2. Biomaterials 2007;28:1027-35

[278] Chen B, Lin H, Zhao Y, Wang B, Zhao Y, Liu Y, Liu Z, Dai J. Activation of demineralized bone matrix by genetically engineered human bone morphogenetic protein-2 with a collagen binding domain derived from von Willebrand factor propolypeptide. J Biomed Mater Res A 2007;80:428-34.

[279] Zhao Y, Chen B, Lin H, Sun W, Zhao W, Zhang J, Dai J. The bonederived collagen containing mineralized matrix for the loading of collagen-binding bone morphogenetic protein-2. J Biomed Mater Res A 2009;88:725-34.

[280] Tuan TL, Cheung DT, Wu LT, Yee A, Gabriel S, Han B, Morton L, Nimni ME, Hall FL. Engineering, expression and renaturation of targeted TGF-beta fusion proteins. Connect Tissue Res 1996;34:1-9.

[281] Andrades JA, Wu LT, Hall FL, Nimni ME, Becerra J. Engineering, expression, and renaturation of a collagen-targeted human bFGF fusion protein. Growth Factors 2001;18:261-75

[282] Lin H, Chen B, Sun W, Zhao W, Zhao Y, Dai J. The effect of collagen-targeting platelet-derived growth factor on cellularization and vascularization of collagen scaffolds. Biomaterials 2006:27:5708-14.

[283] Zhang Y, Xiang Q, Dong S, Li C, Zhou Y. Fabrication and characterization of a recombinant fibronectin/cadherin bio-inspired ceramic surface and its influence on adhesion and ossification in vitro. Acta Biomater 2010;6:776-85.

[284] Ishikawa T, Terai H, Yamamoto T, Harada K, Kitajima T. Delivery of a growth factor fusion protein having collagen-binding activity to wound tissues. Artif Organs 2003;27:147-54.

[285] Elloumi I, Kobayashi R, Funabashi H, Mie M, Kobatake E. Construction of epidermal growth factor fusion protein with cell adhesive activity. Biomaterials 2006;27:3451-8.

[286] Sun W, Lin H, Chen B, Zhao W, Zhao Y, Dai J. Promotion of peripheral nerve growth by collagen scaffolds loaded with collagen-targeting human nerve growth factor-beta. J Biomed Mater Res A 2007;84:1054-61. 